\title{
ASSET MISPRICING
}

\author{
Kurt F. Lewis \\ Francis A. Longstaff \\ Lubomir Petrasek \\ Working Paper 23231 \\ http://www.nber.org/papers/w23231
}

\author{
NATIONAL BUREAU OF ECONOMIC RESEARCH \\ 1050 Massachusetts Avenue \\ Cambridge, MA 02138 \\ March 2017
}

We are grateful for the comments of Dan Covitz, Yesol Huh, Sebastian Infante, Dan Li, and seminar participants at the Federal Reserve Board and UCLA. The analysis and conclusions set forth are those of the authors and do not indicate concurrence by other members of the research staff or the Federal Reserve Board. All errors are our responsibility. The views expressed herein are those of the authors and do not necessarily reflect the views of the National Bureau of Economic Research.

At least one co-author has disclosed a financial relationship of potential relevance for this research. Further information is available online at http://www.nber.org/papers/w23231.ack

NBER working papers are circulated for discussion and comment purposes. They have not been peer-reviewed or been subject to the review by the NBER Board of Directors that accompanies official NBER publications.

(C) 2017 by Kurt F. Lewis, Francis A. Longstaff, and Lubomir Petrasek. All rights reserved. Short sections of text, not to exceed two paragraphs, may be quoted without explicit permission provided that full credit, including $\odot$ notice, is given to the source. 
Asset Mispricing

Kurt F. Lewis, Francis A. Longstaff, and Lubomir Petrasek

NBER Working Paper No. 23231

March 2017

JEL No. G12

\begin{abstract} empirical support for a number of current theoretical models.

Kurt F. Lewis

Federal Reserve Board

Kurt.F.Lewis@frb.gov

Francis A. Longstaff

UCLA

Anderson Graduate School of Management

110 Westwood Plaza, Box 951481

Los Angeles, CA 90095-1481

and NBER

francis.longstaff@anderson.ucla.edu

Lubomir Petrasek

Federal Reserve System

Lubomir.Petrasek@frb.gov
\end{abstract}

We use a unique dataset of corporate bonds guaranteed by the full faith and credit of the U.S. to test a number of recent theories about why asset prices may diverge from fundamental values. These models emphasize the role of funding liquidity, slow-moving capital, the leverage of financial intermediaries, and other frictions in allowing mispricing to occur. Consistent with theory, we find there are strong patterns of commonality in mispricing and that changes in dealer haircuts and funding costs are significant drivers of mispricing. Furthermore, mispricing can trigger short-term margin and funding-cost spirals. Using detailed bond and dealer-level data, we find that most of the cross-sectional variation in mispricing is explained by differences in dealer funding costs, inventory positions, and trading liquidity measures. These results provide strong 


\section{INTRODUCTION}

One of the central doctrines of modern financial theory is that the price of a security should equal the present value of its cash flows. Recently, however, this paradigm has been challenged by examples of asset prices that appear to diverge from their fundamental values, particularly during financial crises and major market events. There is a rapidly growing theoretical literature that focuses on the role of market frictions and constraints in explaining deviations from fundamental values. Important examples include models that consider the effects of funding liquidity, slow-moving capital, and the capital structure of financial intermediaries on asset prices.

In this paper, we use a unique data set of corporate bonds explicitly guaranteed by the full faith and credit of the U.S. to explore the empirical implications of a number of these models. The key advantage of this data set is that since these bonds have the same credit risk as Treasury bonds, deviations from their fundamental values can be observed directly by contrasting their prices with those of comparable Treasury bonds. It is important to note that this type of mispricing represents a violation of the law of one price in the most fundamental sense. In particular, it implies that we could form portfolios of bonds with net cash flows that are zero in all states of the world, but with market prices that differ from zero - something that clearly cannot be reconciled with any stochastic discount factor. Furthermore, we also have proprietary data on the funding costs, haircuts, and inventory positions of the primary dealers making markets in each individual bond. Thus, this panel data set is ideally suited for examining both the time series and cross-sectional implications of these theoretical models for asset mispricing.

We focus on four specific empirical implications of this literature. First, models such as Brunnermeier and Pedersen (2009), Duffie (2010), and others imply that deviations from fundamental values may arise when dealers face funding and capital constraints. If so, then mispricing should not be asset specific. Rather, we would expect to observe commonality in mispricing across all assets traded by the same set of dealers. Second, the availability of trading and arbitrage capital plays a central role in many existing models such as Gromb and Vayanos (2002), Brunnermeier and Pedersen (2009), Gârleanu and Pedersen (2011), Kondor and Vayanos (2015), and others. These models all share the common empirical implication that changes in the cost and availability of capital should drive changes in the deviation from fundamental value over time. Third, models such as Brunnermeier and Pedersen (2009) and Gârleanu and Pedersen (2011) raise the possibility that asset mispricing may lead to destabilizing margin spirals. Finally, many models imply that cross-sectional differences in mispric- 
ing should be related to differences across the financial intermediaries trading these assets in terms of their leverage, funding costs, and capital, as well as to differences in the search costs and other frictions faced by market participants in trading the assets.

We begin by documenting that there is significant and persistent mispricing among the guaranteed corporate bonds in the data set during the 2008-2012 sample period. The overall average value of the mispricing during the sample period is 20.07 basis points. We find, however, that there is dramatic variation in the amount of mispricing over time as well as across bonds.

We turn next to the four empirical implications described above. First, we find that there is a high degree of commonality in the mispricing across the bonds in the sample. In particular, 66 percent of the variation in mispricing is explained by the first principal component, while 82 percent is explained by the first three principal components. These large values provide strong support for implications about commonality inherent in many current models. On the other hand, however, these values also suggest that not all of the variation in mispricing is common across bonds - that there is substantial remaining idiosyncratic variation in mispricing.

Second, we regress weekly changes in the average mispricing of the bonds in the sample on changes in measures reflecting the margins and funding costs faced by dealers in this market. In particular, we have data on the average haircuts that dealers must pay to finance their inventories along with the average dealer CDS spreads and Libor-OIS funding spreads in the market. We find that an increase in the margin or haircut for these bonds leads to a significant increase in mispricing. Similarly, an increase in either the CDS spread or the Libor-OIS funding spread results in higher mispricing. These results provide direct support for a number of theoretical models emphasizing the role that dealer funding and capital constraints play in allowing assets to deviate from their fundamental values.

Third, we examine whether mispricing has the potential to be destabilizing in the sense of allowing spirals to occur. We use a simple vector autoregression approach to explore the relations between bond mispricing, margins, and the funding costs of dealers in the market. We find that an increase in mispricing leads to a short-term increase in margins, which provides support for the margin spiral hypothesis. In addition, we find evidence that an increase in mispricing also leads to an increase in funding costs for dealers, implying the possibility that funding spirals may also occur.

Fourth, we use the full panel data set of mispricings to test directly the implications of the various models at the individual bond level. We find strong 
evidence that the cross-sectional distribution of mispricing is positively related to the CDS spreads and haircuts for the primary dealers making markets in the individual bonds. In addition, we find that mispricing declines significantly as the inventory held by dealers increases. Both the outstanding amount of the bond issue and the total trading volume are significantly related to mispricing. In contrast, other liquidity metrics such as the effective bid-ask spread are not significantly related to mispricing.

A number of important lessons about asset pricing can be drawn from these results. First, the evidence indicates that there is a high degree of commonality in the deviations of asset prices from their fundamental values. Thus, mispricing may represent an important source of systematic risk to investors in the financial markets. In fact, in addition to being systematic in nature, mispricing may actually have toxic effects on markets through its destabilizing effects on margins and dealer funding costs. Second, the positive relation between mispricing and dealer funding costs strongly argues that recent theories focusing on the role that capital constraints play in asset pricing are going in the right direction. Finally, these results provide clear evidence that asset prices can be driven by forces that are unrelated to either cash flows or discount rates, conflicting with the classical paradigm that asset prices are equal to the present value of their cash flows.

This paper contributes to a growing empirical literature focusing on asset mispricing. The paper most similar to ours is Longstaff (2004) who studies the pricing of government-guaranteed Refcorp bonds. He finds that deviations of Refcorp bonds from their fundamental values are related to measures of bond market liquidity. Bai and Collin-Dufresne (2011) study the mispricing of CDS contracts relative to corporate bonds during the financial crisis. They find that funding risk, counterparty risk, and collateral quality are important factors in explaining mispricing. Fleckenstein, Longstaff, and Lustig (2014) study the pricing of Treasury TIPS and show that they were often severely mispriced relative to Treasury bonds during the recent financial crisis. They find that average mispricing is related to issuance, hedge fund flows, and mispricing in other markets. Other important work in this area includes MacKinlay and Ramaswamy (1988), Cornell and Shapiro (1989), Amihud and Mendelson (1991), Boudoukh and Whitelaw (1991), Kamara (1994), Grinblatt and Longstaff (2000), Basak and Croitoru (2000) Jordan, Jorgensen, and Kuipers (2000), Mitchell, Pulvino, and Stafford (2002), Lamont and Thaler (2003), Ofek, Richardson, and Whitelaw (2004), Roll, Schwartz, and Subrahmanyam (2007), Brennan and Wang (2010), and Cremers and Weinbaum (2010). This paper differs significantly from previous work by using both an extensive panel data set of mispricings and a detailed data set about dealer funding costs and capital constraints to test directly the empirical implications of a number of current theories about the determinants of asset mispricing. 
The paper is organized as follows. Section 2 provides a brief literature review. Section 3 discusses some of the major empirical implications of the theoretical literature. Section 4 describes the FDIC Debt Guarantee Program. Section 5 presents the data. Section 6 describes how bond mispricing is identified. Section 7 examines the commonality in mispricing. Section 8 explores the time series behavior of asset mispricing. Section 9 studies whether mispricing is destabilizing. Section 10 examines the cross-sectional pattern of mispricing. Section 11 presents concluding remarks.

\section{LITERATURE REVIEW}

There are many theoretical models in the literature that imply the possibility that asset prices may diverge from fundamental values in the presence of market frictions and financial constraints. This literature, however, is far too extensive for us to review fully here. Instead, our objective in this section is simply to highlight some of the major types of models that have appeared recently in this literature. These are described individually below.

\subsection{Funding Liquidity}

A number of recent papers argue that disruptions in the ability of market participants to obtain funding can lead to situations in which prices can diverge from fundamentals. Important examples include Chowdhry and Nanda (1998) who show that margin constraints can result in prices that move independently of fundamentals. Gromb and Vayanos (2002) present a model in which restrictions on cross margining place wealth related constraints on the ability of investors to arbitrage away mispricing. Brunnermeier and Pedersen (2009) present a model in which margin constraints and changes in speculator capital can result in asset prices diverging from fundamental values (they define market liquidity as the absolute difference of the market price from the fundamental value). Liu and Longstaff (2004) show that optimal trading strategies in markets with margin constraints can allow asset mispricing to persist. Other important examples include Grossman and Vila (1992), Basak and Croitoru (2000), and Gârleanu and Pedersen (2011).

\subsection{Slow-Moving Capital}

A recent paper by Duffie (2010) emphasizes the role that slow-moving capital may play in allowing market prices to diverge from fundamentals. One way in which this can occur is in opaque markets where trading may be delayed by search. In 
such a market, supply shocks may be associated with price impacts and reversals as sellers offer price concessions to obtain immediacy. Important examples of the effects of search on markets and asset pricing include Wolinsky (1990), Duffie, Gârleanu, and Pedersen (2005, 2007), Vayanos and Tang (2007), Weill (2007), Vayanos and Weill (2008), Duffie and Strulovici (2012), Duffie, Malamud, and Manso (2015), and many others. Another mechanism which may lead to slowmoving capital is if investors are not perfectly attentive to the markets at all times. Duffie presents a model in which investor inattention can lead to both overreactions and underreactions to supply shocks. Other important examples of this literature include Lynch (1996), Caballero (1995), Gabaix and Laibson (2001), Chien, Cole, and Lustig (2012).

\subsection{Intermediary Capital}

A rapidly growing literature focuses on the relation between asset prices and the capital of financial intermediaries. While these papers have many similarities with the funding liquidity literature described above, He and Krishnamurthy (2013) argue that there are important differences between the two literatures. In particular, the funding liquidity literature focuses on debt constraints, while the intermediary capital literature focuses more on constraints on raising equity capital. As one example, Kondor and Vayanos (2015) study a model in which arbitrageurs provide liquidity to other traders who seek to hedge their portfolio risk. The arbitrageurs' ability to provide insurance, however, is limited by their capital which becomes a key state variable affecting asset prices. He, Kelly, and Manela (2016) argue that the equity capital ratio of financial intermediaries is likewise an important state variable. In contrast, Adrien, Etula, and Muir (2014) emphasize the role of intermediary leverage ratios. Other important examples of this literature include Allen and Gale (2000), Xiong (2001), Kyle and Xiong (2001), Adrien and Boyarchenko (2012), Basak and Pavlova (2013), Brunnermeier and Sannikov (2014), and others.

\subsection{Liquidity Effects}

There is an extensive literature considering the impact of illiquidity on asset prices. Key examples of research focusing on the implications of transaction costs include Demsetz (1968), Amihud and Mendelson (1986), Boudoukh and Whitelaw (1993), Vayanos (1998), Vayanos and Vila (1999), Acharya and Pedersen (2005), Amihud, Mendelson, and Pedersen (2005), Huang and Wang (2009, 2010), and others. In many of these papers, bid-ask spreads and other forms of transaction costs drive a wedge between the fundamental cash flows of the security and the cash flows actually received by investors. In turn, these differences have the potential to impact market prices. The effects of alternative forms 
of illiquidity on asset prices are studied in Longstaff (1995, 2004, 2009, 2016), Pastor and Stambaugh (2003), Eisfeldt (2004), Eisfeldt and Rampini (2006), and others. Shleifer and Vishny (1992, 2011) Coval and Stafford (2007), Coval, Jurek, and Stafford (2009), and others discuss the impact of distressed sales of illiquid assets on prices.

\section{EMPIRICAL IMPLICATIONS FOR ASSET MISPRICING}

Rather than attempting to identify all of the empirical implications of the various types of models described above, we focus on several key themes that appear in the literature and that are potentially testable given the data available to us.

\subsection{Is There Commonality in Mispricing?}

Many of the models in the literature imply that mispricing should display commonalities across assets. For example, Brunnermeier and Pedersen (2009) argue that mispricing is driven by speculators' funding liquidity or capital scarcity. Thus, shocks to speculators' funding constraints and their shadow cost of capital affect all securities which, in turn, results in commonality in observed mispricing. They identify commonality in mispricing as one of the key empirical implications of their model. In a similar way, Duffie (2010) presents a model in which the current and future availability of capital become state variables that may introduce a common factor into the response of asset prices to supply shocks in markets characterized by slow movement of investment capital. This theme also appears in the intermediary capital literature. In particular, a number of the models in this literature share the feature that the constraints faced by intermediaries in obtaining capital limits their ability to absorb portfolio risk. The direct implication of this is that the capital of financial intermediaries should be related to asset mispricing across the markets in which these intermediaries operate. In summary, this literature implies that asset mispricing may stem from a common underlying source such as the cost of investment capital, rather than asset-specific characteristics. In turn, changes in the underlying source may translate into patterns of commonality in asset mispricing.

\subsection{What Drives Asset Mispricing?}

As discussed above, many models in the literature identify the cost and availability of investment capital as key determinants of asset mispricing. For example, Gromb and Vayanos (2002), Brunnermeier and Pedersen (2009), Gârleanu and Pedersen (2011), and many others imply that asset mispricing may be driven by the margins and funding costs faced by market participants. Similar implications follow directly from models that focus on the role of slow-moving capital and the 
capital constraints faced by financial intermediaries.

\subsection{Is Mispricing Destabilizing?}

Margins play a central role in many of the models in the funding liquidity literature described above. In particular, when speculators or intermediaries face increasing margins, these market participants require additional investment capital to trade. Brunnermeier and Pedersen (2009) model the effects of margins on asset mispricing, and describe the possibility of destabilizing margin spirals occurring as increases in mispricing lead to further rounds of margin tightening. These results imply that there may be feedback effects between asset mispricing and the margins faced by market participants. Similar effects are also possible in other models of the effects of margins on asset pricing such as Gârleanu and Pedersen (2011).

\subsection{What Explains the Cross Section of Mispricing?}

As noted above, a common theme throughout the literature is that the funding or capital constraints experienced by dealers, arbitrageurs, or other financial intermediaries may allow deviations between prices and fundamental values to occur. A direct implication of this is that asset mispricing may be a reflection of the constraints faced by the institutions that own or trade the asset. If various assets are traded by different classes of investors, then it is natural that the differences across these investors in terms of their funding and capital constraints could map into cross-sectional variation in the mispricing of these assets. For example, the results in Brunnermeier and Pedersen (2009) suggest that cross-sectional variation in asset mispricing may be related to cross-sectional differences in the margins and funding costs experienced by the dealers who own or trade those assets. Similarly, Duffie (2010) implies that the amplitude and time series pattern of asset mispricing after a shock is a reflection of institutional impediments to trade. Clearly, differences in the degree of these impediments across institutions could translate into cross-sectional differences in asset mispricing. Liu and Longstaff (2004) present a model in which the time until the final maturity or convergence date of an asset plays a central role in determining the distribution of asset mispricing. Finally, the literature on the effects of illiquidity identifies a number of potential asset-specific factors that could affect asset mispricing. Examples include bid-ask spreads and other types of transaction costs, trading activity, the amount of the asset available in the market, dealer inventories, etc.

\section{THE FDIC DEBT GUARANTEE PROGRAM}

Our approach to identifying asset mispricing is to compare the yields on corporate 
bonds that are explicitly guaranteed by the full faith and credit of the U.S. with those of comparable U.S. Treasury bonds. This approach closely parallels Longstaff (2004) who studied the relative pricing of Refcorp and U.S. Treasury bonds.

In particular, we focus on the pricing of corporate bonds that were issued under a debt guarantee program administered by the Federal Deposit Insurance Corporation (FDIC). In the wake of the failure of Lehman Brothers, and as part of a coordinated response within the U.S. government to what was described as the collapse of credit markets, the FDIC introduced the Temporary Liquidity Guarantee Program on October 14, 2008. This program consisted of two parts: the Transaction Account Guarantee Program which involved a FDIC guarantee in full of all noninterest-bearing accounts, and the Debt Guarantee Program which involved a guarantee of certain newly issued unsecured debt. The bonds we consider were issued as part of the Debt Guarantee Program.

In October of 2008, huge disruptions to credit markets had driven spreads to record levels at a time when financial institutions had a large quantity of unsecured debt scheduled to mature. Concerned that an inability to refinance this existing debt would push already-strained institutions into failure, the goal of the Debt Guarantee Program was to allow institutions to roll over senior unsecured debt by issuing new debt in their own name, backed by a government guarantee. The program provided a guarantee for debt issued by FDIC-insured depository institutions as well as their parent bank holding companies. ${ }^{1}$ The guarantee was for newly-issued debt only, and (ultimately) that debt needed to be issued before the end of October 2009 and the guarantee expired on December $31,2012 .^{2}$

U.S. Treasury bonds are guaranteed by the full faith and credit of the United States. It is important to note that the FDIC guarantee is also explicitly backed by the full faith and credit of the United States. Specifically, the FDIC's Final Rule issued in November 2008, states that the FDIC's guarantee of qualifying credit debt under the Debt Guarantee Program is subject to the full faith and credit of the United States pursuant to Section 15(d) of the FDI Act, 12 U.S.C. 1825(d). In fact, the Master Agreement for the Debt Guarantee Program contains

\footnotetext{
${ }^{1}$ Savings and loan corporations with certain business models as well as other financial entities were also allowed to use the program subject to case-by-case approval.

${ }^{2}$ Both the issuance window and the end of the guarantee given here are the result of deadline extensions that occurred in 2009. For a more detailed discussion of the program, its initial terms and subsequent evolution, see https://www.fdic.gov/ regulations/resources/tlgp/archive.html.
} 
the requirement that the following text be included, exactly as written, in each security issued under the program:

The parties to this Agreement acknowledge that the Issuer has not opted out of the debt guarantee program (the Debt Guarantee Program) established by the Federal Deposit Insurance Corporation (FDIC) under its Temporary Liquidity Guarantee Program. As a result, this debt is guaranteed under the FDIC Temporary Liquidity Guarantee Program and is backed by the full faith and credit of the United States. The details of the FDIC guarantee are provided in the FDICs regulations, 12 CFR Part 370, and at the FDICs website, www.fdic.gov/tlgp. The expiration date of the FDICs guarantee is the earlier of the maturity date of this debt or June 30, 2012.

Furthermore, the Master Agreement is explicit in describing the nature of the guarantee: the bondholder will continue to receive timely payment of principal and interest. That is, for the lifetime of the guarantee program, payments will continue as scheduled regardless of the default of the issuer. ${ }^{3}$ The guarantee is not merely against the bonds principal, the cash flows as scheduled in the bond are guaranteed.

Finally, we observe that the explicit full faith and credit guarantee of corporate debt issued under the FDIC program was honored ex post. In particular, the FDIC reported in its summary of the Temporary Liquidity Guarantee Program that it fully covered the losses suffered by debtholders from the defaults by six financial institutions that participated in the program. The total amount of the defaulted principal and interest payments covered by the FDIC was $\$ 153$ million. ${ }^{4}$

\section{THE DATA}

A unique feature of our study is the availability of several proprietary data sets that will allow us to test directly some of the key empirical implications identified

\footnotetext{
${ }^{3}$ Though allowed by the DGP, no one issued debt under the program for longer than the guarantee period, so this guarantee was applicable through the full lifetime of all of the bonds used in our study.

${ }^{4}$ The six defaulting institutions (and the par amount of defaulted debt) were Integra Bank ( $\$ 51$ million), Bradford Mid-Tier Company ( $\$ 2$ million), Coastal Community Bank (\$3.8 million), Washington First Financial Group (\$34.4 million), the Park Avenue Bank (\$20 million), and Superior Bank (\$40 million).
} 
earlier. First, we are fortunate to have access to a private version of the Trade Reporting and Compliance Engine (TRACE) database. This version differs from the public version of TRACE in that it explicitly identifies the dealers involved in each transaction and includes the actual size of each transaction. ${ }^{5}$ An important advantage of this is that we can definitively identify the primary dealer for each corporate bond in the sample since the TRACE data allow us to infer the trading activity and inventory holdings for each dealer in the market. Second, we also have access to a supervisory data set containing information about the haircuts or funding constraints faced by each major dealer in the market. In conjunction with the TRACE data, this provides us with detailed information about the funding costs for both the primary dealer as well as the lead underwriter for each of the bonds in the sample. Summary statistics for the variables described in this section are given in Table 1.

\subsection{The Corporate Bond Pricing Data}

The sample of guaranteed corporate bonds consists of 63 fixed coupon bonds issued under the Debt Guarantee Program of the FDIC and publicly traded during the sample period from December 2008 to December 2012. As required by the terms of the program, all of the bonds have fixed principal and bullet maturity terms, are senior in the capital structure, and have no special features such as call, put, sinking fund, or conversion provisions. The data source for bond characteristics such as the bond type, issue date, outstanding amount, maturity, and coupon rate is the Fixed Income Securities Database (FISD). We limit the sample to bonds that make fixed semi-annual coupon payments and have at least 180 days to maturity, and thus the data used in the study concludes with trades occurring on June 28, 2012.

The data on secondary-market transactions and prices of these bonds are from the private version of TRACE. This database contains all over-the-counter trades in publicly traded U.S. corporate bonds, including those issued under the Debt Guarantee Program. ${ }^{6}$ We compute the closing transaction price for each trading day based on institutional sized trades with a volume of at least $\$ 100,000$. These trades account for more than 98 percent of the total trading volume.

\footnotetext{
${ }^{5}$ In contrast, the public version of TRACE data used in most other studies is subject to a dissemination cap of $\$ 5$ million per transaction, and all transactions in excess of $\$ 5$ million are disseminated as $\$ 5 \mathrm{MM}+$.

${ }^{6}$ We filter out erroneous and duplicate entries using the procedure described in Goldstein, Hotchkiss, and Sirri (2007), which removes 31 percent of TRACE entries that are trade reversals, cancellations, exact duplicates, or inconsistent with reporting guidelines.
} 


\subsection{Primary Dealer Data}

For each bond and for each month during the sample period, we identify the primary dealer as the dealer with the largest inventory holdings of the bond at the end of the previous month. The details on how the inventory holdings for each dealer are determined are given in the Appendix. ${ }^{7}$

Once the primary dealer for a bond is identified, we use a confidential data set from the Federal Reserve Bank of New York to identify the haircut that the primary dealer must pay to obtain repo financing for corporate bonds. The haircut affects the amount of outside financing the primary dealer needs to support inventory purchases and is an important determinant of the dealer's funding liquidity (see Brunnermeier and Pedersen (2009)). This data set consists of disaggregated data on haircuts on corporate bond collateral posted by individual dealers in the tri-party repo market. The tri-party repo market is a key source of short-term secured funding for securities dealers who typically use the market to finance their inventory purchases (see Copeland, Duffie, Martin, and McLaughlin (2012)). A third party, called a clearing bank, facilitates the settlement of tri-party repos by transferring securities and cash from dealers to cash lenders such as money market funds, securities lenders, and other institutional funding providers. Cash lenders in this market generally accept a wide range of eligible securities as collateral, and transaction terms are set for broad collateral classes such as corporate bonds rather than for specific securities. The market value of the securities posted as collateral customarily exceeds the amount of cash financing received from the repo counterparty by an amount called the "haircut."

Another important determinant of the cost of obtaining funding is the primary dealer's credit risk as a counterparty. To measure this, we obtain daily market prices for five-year credit default swaps (CDS) contracts on the primary dealer. The source of this CDS data is Markit. As discussed by Duffie and Liu (2001), Longstaff, Mithal, and Neis (2005), Blanco, Brennan, and Marsh (2005), and many others, CDS spreads reflect the market price of insuring against the default by the firm or entity underlying the CDS contract. Thus, an increase in the cost of protecting against a default by the primary dealer maps directly into an increase in the primary dealer's cost of unsecured funding. In turn, this has both direct and indirect effects on the primary dealer's ability to obtain funding (funding liquidity).

In corporate bond markets, the lead underwriter of a bond issue often con-

\footnotetext{
${ }^{7}$ As a robustness check, we use an alternative definition of the primary dealer as the dealer who handled the highest percentage of trading volume during the previous month. The empirical results using this alternative definition are very similar to those we report.
} 
tinues to function as a market maker after the bond is issued. Thus, the lead underwriter often fulfills a role that parallels that of the primary dealer. In fact, the lead underwriter may actually be the primary dealer for a bond issue in some cases. In light of this, we use the data sources described above to obtain information about the haircut and CDS spread for the lead underwriter for each of the bonds in the sample. The lead underwriter for each bond is explicitly identified in the FISD database and we cross-check this information with the prospectus. ${ }^{8}$ We use these measures of the funding costs of the lead underwriter in parallel with those for the primary dealer throughout the analysis in the paper.

Finally, we also obtain CDS spreads for the issuers of the individual bonds in the sample from Markit. We use this information to test whether the credit risk of the issuer is related to the mispricing of these corporate bonds. Clearly, given the full faith and credit guarantee, the credit risk of the issuer should not affect the pricing of these bonds.

\subsection{Institutional Ownership Data}

As described above, the TRACE dataset allows us to estimate the inventory holdings of each dealer in the market for each of the bonds in the sample. We total these inventory holding across all dealers and divide by the total amount outstanding to measure the fraction of the bond issue held in inventory by dealers. We also use the number of dealers holding positions in the bonds in the analysis.

Additional data on institutional bond holdings is obtained from the eMAXX database. This data source provides quarterly measures of the amount of each bond in the sample that is held by institutions such as insurance companies, mutual funds, public pension funds, endowment funds, and foundations. Although the data on bond holdings does not cover the entire universe of institutional investors (most bank holding company holdings, for example, are not represented), it provides the best available coverage for most asset manager types. We construct two measures of institutional bond holdings based on the eMAXX database: the number of institutional investors holding a given bond in each quarter, and the percentage of the outstanding amount of the bond held by the institutional investors.

\subsection{Liquidity Measures}

A number of metrics have been proposed to measure bond liquidity and trading activity. In this study, we use a variety of these measures. First, we use the outstanding amount of the bond issue as a measure of its availability or liquidity

${ }^{8}$ If there are multiple underwriters, the first underwriter is designated as the lead underwriter. 
in the market. Second, we use a dummy variable that takes value one if the bond is issued as a medium-term note, and zero otherwise. This measure controls for the possibility that medium-term notes may be less liquid than bonds. Third, we include the daily effective bid-ask spread computed using the TRACE data. Fourth, we include the total trading volume for each bond which is also computed using the TRACE data set (which includes the size of each transaction). Finally, we compute the Amihud illiquidity measure defined as the price change per million dollars traded. The Appendix provides a detailed description on how the effective bid-ask spread, total trading volume, and Amihud illiquidity measure are estimated.

\section{MISPRICING OF GUARANTEED CORPORATE BONDS}

In this section, we begin by describing how mispricing of the guaranteed corporate bonds in our sample is identified. We then examine the properties of the mispricing. To identify mispricing, we use a two-stage procedure. In the first stage, we take the difference between the yield on a guaranteed corporate bond and the yield on an equivalent Treasury bond. In the second stage, we subtract from the yield spread a small component due to the difference in the state income taxation of corporate and Treasury bonds.

\subsection{The Yield Spread}

We calculate the yield spread between the guaranteed corporate bonds and Treasury bonds by taking the difference in the yield to maturity for the corporate bond and the yield to maturity for a Treasury bond with the identical coupon rate and maturity date. To determine the yields for these matching Treasury bonds, we use the daily spot curve constructed from off-the-run fixed-coupon Treasury securities with residual maturities of 90 days or more. The zero coupon Treasury curve is generated using the functional form proposed by Nelson and Siegel (1987) as extended by Svennson (1994). A detailed description of the estimation methodology is given in Gurkaynak, Sack, and Wright (2006). From the fitted Treasury spot curve, we calculate the price of a Treasury bond with the same coupon and maturity as the corporate bond and determine the yield spread.

\subsection{The State Income Tax Adjustment}

As discussed in Elton, Gruber, Agrawal, and Mann (2001), corporate bonds are subject to state income taxation while Treasury bonds are not. Thus, if the marginal investor in these guaranteed corporate bonds is a taxable entity, then part of the yield spread may represent the effect of the marginal state income 
tax rate on the cash flows received by the investor. Following the same line of analysis as in Elton, Gruber, Agrawal, and Mann, the Appendix shows that the portion of the yield spread due to the state income tax effect is simply $c \tau_{s}(1-\tau)$, where $c$ is the coupon rate, $\tau_{s}$ is the marginal state income tax rate, and $\tau$ is the marginal federal income tax rate.

Historically, the effect of state income taxes on corporate bonds has been difficult to identify since yield spreads are also affected by the credit risk of the issuer (see the discussion in Elton, Gruber, Agrawal, and Mann (2001)). In our case, however, all of the corporate bonds have the same credit risk. Thus, the effect on the marginal state income tax rate on the yield spreads of the bonds can be estimated directly from a cross-sectional regression of yield spreads on coupon rates. As is shown in the Appendix, the resulting estimate of $\tau_{s}(1-\tau)$ is 0.01655. From Table 1, the average coupon rate for the bonds in the sample is 2.32 percent. Thus, the average size of the state income tax effect is only on the order of 3.8 basis points. Given the estimated marginal state income tax effect, we solve for the mispricing of the guaranteed corporate bonds by subtracting 0.01655 times the coupon rate of the bond from the yield spread. ${ }^{9}$

\subsection{The Mispricing Estimates}

Table 2 provides summary statistics for the mispricing of each of the bonds in the sample. The average mispricing is positive and highly statistically significant for all 63 bonds in the sample. The average mispricing across all bonds is 20.07 basis points. The median mispricing across all bonds is 14.07 basis points. Furthermore, 91.72 percent of all mispricing estimates are positive. These results provide strong evidence that guaranteed bonds with the same cash flows as Treasury securities trade at a significant spread to Treasuries during most of the sample period - a clear violation of the law of one price.

Figure 1 plots the time series of average mispricing across all bonds in the sample. As shown, there is considerable time series variation in mispricing over time. Average mispricing reaches a peak of roughly 200 basis points in early 2009, but then shows a declining trend during most of the sample period. By the end of the sample period, average mispricing converges to near zero.

A notable feature of the data, however, is the large dispersion of mispricing across bonds at any given point in time. This is shown in Figure 2 which plots

\footnotetext{
${ }^{9}$ To ensure that the results are robust to the estimate of the marginal state income tax rate, we reestimate all the time series and cross-sectional regressions in the paper with the coupon rate (or change in the coupon rate) included as a control. The results from these regressions are virtually identical to those we report.
} 
the mispricing estimates for all of the bonds in the sample. During much of the sample period, the cross-sectional standard deviation of mispricing is in the range of 20 to 30 basis points. Even near the end of the sample period when average mispricing has converged to nearly zero, we still see evidence of significant crosssectional dispersion in individual mispricing estimates. In subsequent sections, we will use both the time series and cross-sectional variation in the mispricing of these bonds to test directly the empirical implications of the models identified earlier.

\section{IS THERE COMMONALITY IN MISPRICING?}

The theoretical literature on mispricing offers two complementary perspectives. On one hand, the theory provides a number of potential reasons why mispricing for individual assets may occur. These include security-specific transaction costs and other types of illiquidity. On the other hand, many of the models in the literature such as Brunnermeier and Pedersen (2009) and Duffie (2010) imply that mispricing should display commonality across assets. In this section, we examine how much of the variation in the mispricing of guaranteed bonds can be attributed to common factors.

To this end, we first compute pairwise correlations for the mispricing of the bonds in the sample. In particular, we compute the correlation between the mispricing of all pairs of bonds for which there are at least 100 days with data for both bonds during the sample period. This results in a set of 1659 pairwise correlations. The average pairwise correlation is 0.74 . The standard deviation of the pairwise correlations is 0.22 . The histogram of these pairwise correlations is shown in Figure 3. As shown, the pairwise correlations follow a bimodal distribution with one mode centered at about 0.70 and the other at about 0.90 . The vast majority of the pairwise correlations are greater than 0.50 . Just over ten percent of the bonds, however, have correlations of less than 0.50. Furthermore, about two percent of all pairwise correlations are negative. This distribution of mispricing correlations across the bonds in the sample suggests that mispricing is driven by both common and bond-specific factors.

To provide additional perspective, we also conduct a principal components analysis based on the correlation matrix of mispricing for the bonds. In doing this, we limit the analysis to the 58 bonds for which we have at least 100 daily observations in common with other bonds. Table 3 summarizes the results of the principal component analysis. The first principal component accounts for twothirds of the total variance, and the second principal component explains about an additional 13 percent. Thus, a significant component of the mispricing appears 
common across bonds used in the sample. However, extending the analysis to include as many as the first seven principal components still explains only 90 percent of the variance. This indicates that mispricing is also affected by factors that are specific to the individual bonds.

\section{WHAT DRIVES MISPRICING?}

The previous section shows that a large proportion of the variation in mispricing is driven by common factors, resulting in correlated movements in mispricing. In this section, we explore the factors that drive the common variation in the time series of average mispricing. Specifically, we estimate time series regressions of weekly changes in average mispricing on both contemporaneous and lagged changes in a number of market-wide variables. To calculate the weekly changes in average mispricing, we take the difference between successive end-of-week average mispricing values.

As explanatory variables in the regression, we include several measures of the funding liquidity or capital costs faced by dealers making markets in the bonds. The first is the weighted average haircut that these dealers pay in financing their inventory, where the weights are based on inventory holdings. As discussed in Gromb and Vayanos (2002), Brunnermeier and Pedersen (2009), and many others, changes in the haircut directly affect the amount of capital dealers require to function as market makers. The second variable is the Libor-OIS spread. This spread provides a measure of the funding costs that dealers face in financing contractual positions such as swaps and derivatives. The Libor-OIS spread has been used as a proxy for dealer funding costs in a number of recent papers including Filipovic and Trolle (2013) and Nyborg and Ostberg (2014). ${ }^{10}$ Another important determinant of dealers' capital costs is their credit risk as a counterparty. To capture the impact dealers' credit risk on their funding liquidity, we include the weighted average CDS spread of dealers making markets in these guaranteed bonds, where the weights are based on the inventory positions of these dealers. The dealer CDS spread has been used as a measure of capital constraints in the financial markets in many other studies including Gilchrist and Zakrajsek (2012) and Copeland, Martin, and Walker (2014). Finally, motivated by the discussion in Brunnermeier and Pedersen, we include a measure of market volatility in the regressions. In particular, we use the MOVE index which reflects the implied volatility of interest rates as inferred from interest rate swap options. The Libor-OIS and MOVE index data are obtained from the Bloomberg system. Our

${ }^{10}$ For a detailed discussion of the Libor-OIS spread, see Schwartz (2016), and Sundaresan, Wang, and Yang (2016). 
regressions include four lags of both the dependent variable and the explanatory variables to allow for mean reversion in mispricing and lead-lag effects.

Table 4 summarizes the regression results. In the first specification, we test whether changes in corporate bond haircuts explain changes in average mispricing. The results provide direct support for the funding liquidity models. In particular, changes in mispricing are significantly positively related to both contemporaneous and lagged changes in haircut requirements. The economic magnitude of these effects is likewise very significant. For example, a one-percentage point contemporaneous shock to the haircut is associated with an increase in mispricing by 4.3 basis points, and a lagged shock of the same magnitude translates into an increase in mispricing by as much as 8.8 basis points. These findings confirm the importance of repo market frictions for mispricing.

The next specification in Table 4 includes changes in dealers' CDS spreads along with haircuts. The contemporaneous changes in CDS spreads and up to three lags are significant and positive, consistent with the theory that dealer credit risk drives up their funding costs and increases mispricing. The contemporaneous coefficient estimate indicates that a one-percentage point increase in dealer CDS spreads is associated with an increase in mispricing of 4.9 basis points. Notably, the coefficient on haircuts remains significantly positive after we control for dealer credit spreads, implying that frictions in secured funding markets affect mispricing independently of dealer credit risk.

The third specification in Table 4 includes the Libor-OIS spread among the explanatory variables. As discussed above, the Libor-OIS spread is an important gauge of liquidity in unsecured funding markets. The coefficient estimate on the contemporaneous funding spread is 0.3 , which is significant at the five percent level. As we would expect if credit risk is an important determinant of unsecured funding costs, several lags of CDS spreads become insignificant after we control for the Libor-OIS spread, although the contemporaneous effect of CDS spreads on mispricing remains statistically significant.

These results do not change if we control for bond market volatility in the last column of Table 4. Frictions in both secured and unsecured funding markets, as measured by changes in haircuts and the Libor-OIS spread, are significantly related to mispricing, while dealer credit risk, measured by the CDS spread, remains significant at the 10 percent level. ${ }^{11}$

\footnotetext{
${ }^{11}$ As a robustness check, we also reestimate the regressions in Table 4 using only data from the third quarter of 2009 onward to see if the results are driven primarily by the "peak" of the crisis. The magnitude, signs, and significance of the coefficients are generally similar to those reported in Table 4 (with the exception of the results for changes in haircuts - the coefficient for the contemporaneous
} 


\section{IS MISPRICING DESTABILIZING?}

The Brunnermeier and Pedersen (2009) model presents the possibility of destabilizing spirals in asset prices perpetuated by funding pressures. Proposition 3 in their paper asserts that such a spiral could emerge when haircuts are increasing in non-fundamental factors of asset prices, such as liquidity premia. In the case of a funding shock to speculators, market liquidity falls leading to a reduction in positions by the speculator (that is, sales), which cause higher price volatility, which leads to higher haircuts, which reinforces the need to reduce positions: thus, the spiral.

We think of our measure of mispricing as reflecting a non-fundamental factor that could affect market liquidity. We examine the relationship of this variable with other variables that could themselves represent - or have an effect onfunding liquidity. We do this in the context of a standard reduced-form model of endogenous interaction, the vector autoregression (VAR). Specifically, we examine a four-lag VAR of weekly-Friday average mispricing, haircuts, and the weighted average of the CDS spreads of dealers in the corporate bond market.

Before we begin, we note that the aggregated time series data for mispricing, haircuts and CDS spreads series are not all stationary. For the number of observations we have on this data, an augmented Dickey-Fuller test of the hypothesis that a variable is $I(1)$ against the alternative that it is $I(0)$ has a five-percent critical value of $-2.88 .{ }^{12}$ The test statistic for the mispricing series is -7.20 , a rejection of the unit root null, while the test-statistic for the haircuts series is a borderline (near the ten percent critical value) -2.59 and the statistic for the CDS series indicates that we fail to reject the null of a unit root at -1.99 . Because of the mix of integrated and stationary variables, we conduct the VAR analysis in differences rather than levels for all of the variables, but show a measure of the level effect in the figures below.

The coefficient estimates from the VAR are given in Table 5 and show signs of fairly quick mean reversion. As is frequently the case for financial data, the weekly changes in the variables oscillate fairly rapidly around zero. Moving to the impulse response functions, we examine the interaction among variables in response to orthogonalized shocks. In each case, we begin with the response to an orthogonalized shock to mispricing so that we can examine the model for any

change in haircuts is only significant at the ten percent level).

${ }^{12}$ This relatively small sample likely plays a role in these findings of unit roots, particularly in haircuts. 
signs of mispricing's destabilizing effects. ${ }^{13}$

Our first set of impulse responses, shown in Figure 4, demonstrates behavior that appears somewhat consistent with a spiral story of the kind Brunnermeier and Pedersen (2009) propose. Before we continue, however, it is important to note that we are not asserting that the bonds in our study necessarily follow the spiral mechanics themselves as individual bonds. Instead, what we can examine here with aggregated time series data is the effect of shocks to this nonfundamental factor which could likely be a component within all corporate bond spreads.

The top row of Figure 4 is the response of haircuts to a shock to the mispricing variable. The solid blue line in each figure shows the impulse response function, with the dotted red lines tracing out the path of the 5th and 95th quantiles of the bootstrap distribution of the impulse response function. The panel on the left of the figure is the orthogonalized response of the weekly changes in haircuts to a one standard deviation shock in the weekly changes in average mispricing. The panel on the right is the cumulative version of the same impulse response function, which gives a sense of the level effect in haircuts of a permanent shock to mispricing of the same magnitude. ${ }^{14}$ The bottom row of Figure 4 provides slightly weaker (statistically speaking) evidence consistent with the other half of the spiral story by showing the response of mispricing to haircuts. Again, the left panel shows the orthogonalized response of weekly changes in average mispricing to a one standard deviation shock in average haircuts, with the cumulative measure for this effect in the panel to the right. While the effects we find are not economically large, they are directionally consistent with the idea that a non-fundamental factor, perhaps related with market liquidity, could be interrelated with measure of dealer funding costs in such a way that it may be plausible to generate destabilizing dynamics, as in Brunnermeier and Pedersen (2009).

Figure 5 examines the relationship between mispricing and a measure of the credit risk of dealers in the corporate bond market, their CDS spreads. Likely due to the mitigating effects of fluctuating haircuts - which are themselves moved by mispricing as shown above - we see in the top row of Figure 5 that a shock to

\footnotetext{
${ }^{13}$ The orthogonalization is accomplished simply with Cholesky decomposition and thus the ordering of the VAR variables matters. The ordering used here was CDS, mispricing, haircuts, and the order matters fairly little for the directionality and general contours of the impulse response functions shown, though the statistical significance somewhat varies across orderings.

${ }^{14}$ This was done to balance the need to conduct the VAR in changes with the desire to see level effects.
} 
the average mispricing in the corporate bond market does not appear to have a statistically recognizable effect on the credit risk of intermediaries. Interestingly, when we look at shocks going in the other direction, that is when we examine the effects of shocks to the perceived credit quality of the dealers in corporate bond networks, we find that these shocks do appear to have an effect on mispricing. That is, when the intermediaries in this market experience a shock to CDS spreads that could possibly make their cost of capital or funding cost increase, it increases the average mispricing factor. Thus, it may be possible that a shock to the perceived credit quality of dealers in the corporate bond market could result in the kind of deleveraging that initiates spiral-like behavior through mispricing and haircuts as shown in Figure 4.

To further examine funding relationships, we perform one additional analysis by adding to the VAR the spread of three-month Libor over the three-month overnight indexed swap (OIS) rate, a more direct measure of how counterparty risk in unsecured funding markets increases funding costs. ${ }^{15}$ Figure 6 shows the interplay between shocks in mispricing and shocks to this Libor-OIS spread. The top row shows the effect of an orthogonalized shock to mispricing on these Libor-OIS spreads, while the bottom row shows the effect of a shock to LiborOIS spreads on mispricing. These results, although not economically large, are also consistent with a theory that links funding costs - in unsecured or secured funding markets - with measures of market liquidity.

\section{WHAT EXPLAINS THE CROSS SECTION?}

In this section, we test the cross-sectional implications of the various models discussed earlier. To do this, we regress month-end mispricing on a number of different categories of explanatory variables.

The first category consists of bond-specific characteristics. In particular, we include the time to maturity and the coupon rate for the bonds. We include the time to maturity since it represents the horizon over which the final convergence of the corporate bonds to their fundamental value is guaranteed. Time to convergence plays a central role in determining the properties of potential mispricing in models such as those in MacKinlay and Ramaswamy (1988) and Liu and Longstaff (2004). We use the coupon rate as a control for potential liquidity effects and for any residual state marginal income tax effects.

\footnotetext{
${ }^{15}$ Cholesky decomposition is again used for impulse response orthogonalization in this analysis and the Libor-OIS spread variable is ordered last (CDS, mispricing, haircuts and Libor-OIS).
} 
The second category consists of the CDS spread for the issuer of the bond. In theory, the credit risk of the issuer should not affect the pricing of the bond given the full faith and credit risk guarantee by the U.S. We include the CDS spread of the issuer as a control for the possibility that investors believe that issuer credit risk still plays a factor.

The third category consists of measures of dealer funding constraints and capital costs. We consider two types of intermediaries for each bond: its primary dealer (i.e., the dealer with the largest inventory holdings for the bond at the end of the previous month), and its lead underwriter. The funding constraints of each type of intermediary are measured in two alternative ways: the intermediary's CDS spread and the haircut that the intermediary pays to finance corporate bonds in the tri-party repo market. CDS spreads measure the intermediary's credit risk as a counterparty, and therefore reflect the cost of unsecured funding. Haircuts play an important role in the funding liquidity models of Gromb and Vayanos (2002) and Brunnermeier and Pedersen (2009) because they provide a direct measure of the amount of capital an intermediary must set aside for inventory funding.

The fourth category consists of measures of dealer intermediation and market demographics. In particular, we include the number of dealers that hold positions in each bond as well as the percentage of the total amount outstanding of each bond that is held in inventory by these dealers. The role that dealer intermediation plays in asset pricing is studied in Grossman and Miller (1988), Duffie, Gârleanu, and Pedersen (2005), He and Krishnamurthy (2013), and Adrian, Etula, and Muir (2014). In Grossman and Miller, the equilibrium level of mispricing if market makers supply immediacy by their continuous presence and willingness to bear inventory risk. In Duffie, Gârleanu, and Pedersen (2005), mispricing is lower if investors can more easily find market makers who compete with each other for order flow. In He and Krishnamurthy, financial intermediaries are the marginal investors who determine risk premia during crises. In Adrian, Etula, and Muir, the value of the wealth of financial intermediaries determines the stochastic discount factor. We also include the number of institutional investors who hold positions in excess of $\$ 100,000$ in each bond as well as the percentage of the total amount outstanding of each bond that is held by these institutional investors. Institutional ownership plays a central role in models such as Vayanos and Wang (2005), Duffie, Gârleanu, and Pedersen (2007). In Vayanos and Wang, liquidity concentrates endogenously in assets traded by institutional investors, and this translates into equilibrium price differentials. In Duffie, Gârleanu, and Pedersen (2007), mispricing is smaller when the fraction of qualified owners is greater.

The final category consists of liquidity measures for the individual bonds. 
These include the notional amount of the bond outstanding, the total monthly trading volume, the effective bid-ask spread, the Amihud measure of price impact, and an indicator that takes value one if the bond was issued as a mediumterm note, and zero otherwise. These measures are motivated by the extensive literature on liquidity in fixed income markets, and many of these variables have been used as liquidity proxies in previous empirical studies. ${ }^{16}$

In the cross-sectional regressions, mispricing is measured at month end. Issuer and dealer credit risk, dealer haircuts, bond liquidity, and the number of dealers are measured over the previous month, and dealer inventories are measured at the end of the previous month. The number of investors and institutional holdings are measured at the end of the previous quarter. The regressions are estimated with time fixed effects, and standard errors are double clustered by issuer and time period following Thompson (2011).

Table 6 reports the results from cross-sectional regressions of mispricing on the explanatory variables. The first or baseline specification shows that mispricing is strongly related to residual maturity, which alone explains 55 percent of the cross-sectional variation in guaranteed bond spreads. Short-term bonds that are guaranteed by the government are de-facto cash equivalents regardless of their secondary market liquidity because they can be redeemed at maturity with zero price impact or transaction costs. In addition, as discussed by Longstaff, Mithal, and Neis (2005), short-maturity bonds may be more liquid due to institutional demand and the existence of investment clienteles. Our findings confirm the interpretation of time to convergence as an important determinant of bond mispricing, consistent with MacKinlay and Ramaswamy (1988) and Liu and Longstaff (2004). In contrast, coupon is not significantly related to mispricing, as we would expect since mispricing has been adjusted for the state income tax effect. ${ }^{17}$

In the second specification in Table 6, we include the issuers CDS spread among the explanatory variables to examine whether mispricing may in part reflect the residual credit risk of the issuer. The coefficient estimate for the issuer's CDS spread is not statistically significant in this specification, and becomes zero or slightly negative in specifications that include additional explanatory variables. These findings confirm that issuer credit risk is not a significant determinant of

\footnotetext{
${ }^{16}$ For example, see Crabbe and Turner (1995), Chen, Lesmond, and Wei (2007), and Dick-Nielsen, Feldhütter, and Lando (2012).

${ }^{17}$ Without the adjustment for the effect of state income taxes, the estimated coefficient on coupon is 0.01655 , significant at the one percent level-almost exactly equal to the tax effect theorized by Elton, Gruber, Agrawal, and Mann (2001). All other coefficient estimates remain essentially unchanged if we use the unadjusted spreads in the regression.
} 
mispricing in the sample of guaranteed corporate bonds.

We examine next whether bond mispricing is related to intermediary funding constraints and capital costs. The third specification in Table 6 shows that the lead underwriters CDS spread and the primary dealers CDS spread are both significantly positively related to bond mispricing. A one-percentage point increase in the lead underwriters CDS spread is associated with a 2.1 basis point increase in mispricing, and a similar increase in the prime dealers CDS spread is associated with a 1.1 basis point increase in mispricing. In addition, a one-percentage point increase in the haircut on corporate bond collateral posted by the primary dealer is associated with a 0.5 basis point increase in mispricing. These findings show that the secured and unsecured funding costs of dealer intermediaries affect mispricing at the individual bond level, providing strong direct support for the funding liquidity models of mispricing.

In the fourth specification in Table 6 , we test whether mispricing of individual bonds can be explained by the competitive dynamics and dealer intermediation in over-the-counter markets. The number of dealers making markets for a bond is negatively related to its mispricing at the 10 percent significance level, indicating that dealer intermediation reduces mispricing. The number of institutional investors variable is not significant. Dealer inventory holdings are strongly negatively related to mispricing. In particular, a ten-percentage point increase in dealer inventory holdings (as a percentage of the outstanding amount) reduces mispricing by 1.2 basis points. In contrast, the holdings of other institutional investors such as insurance companies and pension or mutual funds are not a significant factor in explaining mispricing. These results support models that stress the importance of dealer intermediation in over-the-counter markets. For example, in the model of Grossman and Miller (1988), the equilibrium level of mispricing is lower if market makers supply immediacy by their continuous presence and willingness to bear inventory risk. In the model of Duffie, Gârleanu, and Pedersen (2005), mispricing is lower if investors can more easily find market makers who compete with each other for order flow. Our findings that bonds with larger dealer inventories and a greater number of dealers and are less mispriced provide empirical support for these theories.

In the fifth specification in Table 6 , we include several commonly used proxies for corporate bond liquidity, such as the outstanding amount, bond type, trading volume, bid-ask spread, and the Amihud measure. The log of the outstanding amount is significantly negatively related to mispricing, indicating that larger bond issues command a premium over small issues. However, the magnitude of the size effect is quite small; a ten percent increase in the outstanding amount is associated with a reduction in mispricing of only -0.16 basis points $(-1.72 * \ln (1.10))$. In addition, the log of trading volume is positively associated 
with mispricing, although the magnitude of the effect of the increase is only 0.07 basis points per ten percent change in volume. Bid-ask spreads and the Amihud measure are not significantly related to mispricing after we control for factors such as dealer intermediation. Notably, the variables related to dealer funding conditions and dealer intermediation such as primary dealer haircuts, CDS spreads, and dealer inventories remain statistically and economically significant, showing that dealer intermediaries are of first order importance in explaining mispricing. ${ }^{18}$

Finally, as a robustness check on the results, we reestimate the cross-sectional regressions with both issuer fixed effects and monthly fixed effects. The regression results are reported in Table 7 . As shown, the results from these cross-sectional regressions are very similar to those reported in Table 6 .

\section{CONCLUSION}

Recent research has documented a number of cases in which securities with essentially identical cash flows frequently trade at different prices. At the same time, a number of theories have been proposed to explain these apparent violations of the law of one price. Foremost among the theoretical explanations are dealer liquidity and funding constraints, the cost and availability of intermediary capital, and liquidity effects along with their implications for transaction costs and asset prices. In this paper, we use a unique data set of corporate bonds explicitly guaranteed by the full faith and credit of the United States combined with proprietary information on the funding costs, haircuts, and inventory positions of the primary dealers making markets in each individual bond to test the empirical implications of these theories.

Our analysis of guaranteed bonds shows a high degree of commonality of mispricing of the bonds in the sample, but it also reveals that there is a substantial bond-specific variation in mispricing. Further time-series tests show that the common variation in mispricing is positively related to the average haircuts that dealers must pay to finance their corporate bond inventories in secured funding markets along with proxies for unsecured funding costs such as the Libor-OIS spread and the average CDS spread of bond dealers. Mispricing also has the

\footnotetext{
${ }^{18}$ For robustness, we reestimate Table 6 using only data from the third quarter of 2009 onward. The results are very consistent with those reported in Table 6. In particular, the significance of the primary dealer and lead underwriter CDS spreads remains the same or becomes stronger, while the impact of primary dealer haircuts weakens slightly ( $t$-statistic drops to 1.85).
} 
potential to be destabilizing in the sense that increases in mispricing lead to short-term increases in margins and dealer funding costs, although the effects are short-lived and dissipate over a period of several weeks.

The bonds in the sample all trade in corporate bond markets but the individual bonds are underwritten and intermediated by heterogeneous dealers. Each of these dealers have different credit risk and access to funding, which allows us to directly test the implications of several theoretical models. Specifically, we find that differences in characteristics of the intermediaries trading specific bonds in the market help to explain the differences in the levels of mispricing across those bonds. Measures of dealer funding constraints and capital costssuch as primary dealer CDS spreads and the haircuts they pay to finance their inventories in tri-party repo - are positively related to mispricing at the individual bond level. Dealer inventories, the number of dealers making markets for a certain bond, and the issue size are all negatively related to mispricing. The issuers credit spread and most bond-specific liquidity metrics are not significantly related to mispricing after accounting for dealer intermediation.

Taken together, these results provide strong support for theoretical models in which disruptions to intermediary funding costs and capacity lead to situations in which prices diverge from fundamental value. In particular, the models based on margin constraints, such as Chowdhry and Nanda (1998), Gromb and Vayanos (2002), and Brunnermeier and Pedersen (2009), are directly supported by our findings that haircuts paid by primary dealers to finance inventory affect mispricing both in the time series and in the cross-section. The implication of Brunnermeier and Pedersen (2009) that mispricing is destabilizing and that haircuts and mispricing are mutually reinforcing is consistent with our finding that increases in mispricing lead to short-term increases in haircuts and funding costs for dealers. Shocks to dealer capital and unsecured funding costs play a similar role as shocks to haircuts, as evidenced by the finding that primary dealer and bond underwriter CDS spreads affect mispricing. These findings broadly support a number of theories such as Adrien, Etula, and Muir (2014) and Kondor and Vayanos (2015) in which intermediary capital constraints affect asset prices. We also find some support for models that emphasize the role of dealers and dealer inventories in over-the counter markets, such as the model of Grossman and Miller (1988) and Duffie, Gârleanu, and Pedersen (2005). Finally, the results provide evidence that asset prices can be driven by forces that are unrelated to either cash flows or discount rates, and may represent an important source of systematic risk to investors since they have a high degree of commonality across assets and are prone to potentially destabilizing dynamics. 


\section{REFERENCES}

Acharya, Viral V., and Lasse H. Pedersen, 2005, Asset Pricing with Liquidity Risk, Journal of Financial Economics 77, 375-410.

Adrien, Tobias, and Nina Boyarchenko, 2012, Intermediary Leverage Cycles and Financial Stability, Federal Reserve Bank of New York Staff Reports, no. 567.

Adrien, Tobias, Erkko Etula, and Tyler Muir, 2014, Financial Intermediaries and the Cross-Section of Asset Returns, Journal of Finance 69, 2557-2596.

Allen, Franklin, and Douglas Gale, 2000, Financial Contagion, Journal of Political Economy 108, 1-33.

Amihud, Yakov, 2002, Illiquidity and Stock Returns: Cross-Section and TimeSeries Effects, Journal of Financial Markets 5, 31-56.

Amihud, Yakov, and Haim Mendelson, 1986, Asset Pricing and the Bid-Ask Spread, Journal of Financial Economics 17, 223-249.

Amihud, Yakov, and Haim Mendelson, 1992, Liquidity, Maturity, and the Yields on U.S. Treasury Securities, Journal of Finance 46, 1411-1425.

Amihud, Yakov, Beni Lauterbach, and Haim Mendelson, 1997, Market Microstructure and Securities Values: Evidence from the Tel Aviv Exchange, Journal of Financial Economics 45, 365-390.

Amihud, Yakov, Haim Mendelson, and Lasse H. Pedersen, 2005, Liquidity and Asset Prices, Foundations and Trends in Finance 1, 269-364.

Ang, Andrew, and Nicolas Bollen, 2010, Locked Up by a Lockup: Valuing Liquidity as a Real Option, Financial Management 39, 1069-1095.

Bai, Jennie, and Pierre Collin-Dufresne, 2011, The CDS-Bond Basis, Working paper, Georgetown University.

Basak, Suleyman, and Benjamin Croitoru, 2000, Equilibrium Mispricing in a Capital Market with Portfolio Constraints, Review of Financial Studies 13, 715748.

Basak, Suleyman, and Domenico Cuoco, 1998, An Equilibrium Model with Restricted Stock Market Participation, Review of Financial Studies 11, 309-341.

Basak, Suleyman, and Anna Pavlova, 2013, Asset Prices and Institutional Investors, American Economic Review 103, 1728-1758. 
Berkman, H., and V. R. Eleswarapu, 1998, Short-Term Traders and Liquidity: A Test Using Bombay Stock Exchange Data, Journal of Financial Economics 47, 339-355.

Blanco, Roberton, Simon Brennan, and Ian W. Marsh, 2005, An Empirical Analysis of the Dynamic Relation Between Investment-Grade Bonds and Credit Default Swaps, Journal of Finance 60, 2255-2281.

Boudoukh, Jacob, and Robert Whitelaw, 1991, The Benchmark Effect in the Japanese Government Bond Market, Journal of Fixed Income 1, 52-59.

Boudoukh, Jacob, and Robert Whitelaw, 1993, Liquidity as a Choice Variable: A Lesson from the Japanese Government Bond Market, Review of Financial Studies 6, 265-292.

Brennan, Michael J., and Ashley Wang, 2010, The Mispricing Return Premium, Review of Financial Studies 23, 3437-3468.

Brenner, Menachem, Rafi Eldor, and Schmuel Hauser, 2001, The Price of Options Illiquidity, Journal of Finance 56, 789-805.

Brunnermeier, Markus, and Lasse H. Pedersen, 2009, Market Liquidity and Funding Liquidity, Review of Financial Studies 22, 2201-2238.

Brunnermeier, Markus, and Yuliy Sannikov, 2014, A Macroeconomic Model with a Financial Sector, American Economic Review 104, 379-421.

Caballero, Ricardo, 1995, Near-rationality, Heterogeneity, and Aggregate Consumption, Journal of Money Credit and Banking 27, 29-48.

Chacko, George C., Jakub W. Jurek, and Erik Stafford, 2008, The Price of Immediacy, Journal of Finance 63, 1253-1290.

Chen, Long, David A. Lesmond, and Jason Wei, 2007, Corporate Yield Spreads and Bond Liquidity, Journal of Finance 62, 119-149.

Chowdhry, Bhagwan, and Vikram Nanda, 1998, Leverage and Market Stability: The Role of Margin Rules and Price Limits, Journal of Business 71, 179-210.

Cole, Hal, Yi-Li Chien, and Hanno Lustig, 2012, Is the Volatility of the Market Price of Risk due to Intermittent Portfolio Rebalancing? American Economic Review.

Constantinides, George M., 1986, Capital Market Equilibrium with Transaction Costs, Journal of Political Economy 94, 842-862.

Copeland, Adam, Darrell Duffie, Antoine Martin, and Susan McLaughlin, 2012, 
Key Mechanics of the U.S. Trip-Party Repo Market, FRBNY Economic Policy Review November, 17-28.

Copeland, Adam, Antoine Martin, and Michael Walker, 2014, Repo Runs: Evidence from the Tri-Party Repo Market, Journal of Finance 69, 2343-2380.

Copeland, Thomas E., and Dan Galai, 1983, Information Effects on the Bid-Ask Spread, Journal of Finance 38, 1457-1469.

Cornell, Bradford, and Alan C. Shapiro, 1989, The Mispricing of U.S. Treasury Bonds: A Case Study, Review of Financial Studies 2, 297-310.

Coval, Joshua D., and Erik Stafford, 2007, Asset Fire Sales (and Purchases) in Equity Markets, Journal of Financial Economics 86, 479-512.

Coval, Joshua D., Jakub W. Jurek, and Erik Stafford, 2009, Economic Catastrophe Bonds, American Economic Review 99, 628-666.

Crabbe, Leland E., and Christopher M. Turner, 1995, Does the Liquidity of a Debt Issue Increase with its Size? Evidence from the Corporate Bond and Medium-Term Note Markets, Journal of Finance 50, 1719-1734.

Cremers, Martijn, and David Weinbaum, 2010, Deviations from Put-Call Parity and Stock Return Predictability, Journal of Financial and Quantitative Analysis 45, 335-367.

Demsetz, Harold, 1968, The Cost of Transacting, Quarterly Journal of Economics 82, 33-53.

Dick-Nielsen, Jens, Peter Feldhutter, and David Lando, 2012, Corporate Bond Liquidity Before and After the Onset of the Subprime Crisis, Journal of Financial Economics 103, 471-492.

Duffie, Darrell, 2010, Asset Price Dynamics with Slow-Moving Capital, Journal of Finance 65, 1237-1267.

Duffie, Darrell, Nicolae Gârleanu, and Lasse H. Pedersen, 2005, Over the Counter Markets, Econometrica 73, 1815-1847.

Duffie, Darrell, Nicolae Gârleanu, and Lasse H. Pedersen, 2007, Valuation in Over-the-Counter Markets, Review of Financial Studies 20, 1865-1900.

Duffie, Darrell, and Jun Liu, 2001, Floating-Fixed Credit Spreads, Financial Analysts Journal 57, 73-87.

Duffie, Darrell, Semyon Malamud, and Gustavo Manso, 2015, Information Percolation in Segmented Markets, Journal of Economic Theory 157, 1130-1158. 
Duffie, Darrell, and Bruno Strulovici, 2012, Capital Mobility and Asset Pricing, Econometrica 80, 2469-2509.

Eisfeldt, Andrea L., 2004, Endogenous Liquidity in Asset Markets, Journal of Finance 59, 1-30.

Eisfeldt, Andrea L., and Adriano Rampini, 2006, Capital Reallocation and Liquidity, Journal of Monetary Economics 53, 369-399.

Elton, Edwin J., Martin J. Gruber, Deepak Agrawal, and Christopher Mann, 2001, Explaining the Rate Spread on Corporate Bonds, Journal of Finance 56, $247-277$.

Filipovic, Damir, and Anders B. Trolle, 2013, The Term Structure of Interbank Risk, Journal of Financial Economics 109, 707-733.

Fleckenstein, Matthias, Francis A. Longstaff, and Hanno Lustig, 2014, The TIPSTreasury Bond Puzzle, Journal of Finance 69, 2151-2197.

Gabaix, Xavier, and David Laibson, 2001, The 6D Bias and the Equity Premium Puzzle, NBER Macroeconomics Annual 16, 257-312.

Gârleanu, Nicolae, and Lasse H. Pedersen, 2011, Margin-Based Asset Pricing and Deviations from the Law of One Price, Review of Financial Studies 22, 4259-4299.

Gilchrist, Simon, and Egon Zakrajsek, 2012, Credit Spreads and Business Cycle Fluctuations, The American Economic Review 102, 1692-1720.

Glosten, Lawrence R., and Lawrence E. Harris, 1988, Estimating the Components of the Bid/Ask Spread, Journal of Financial Economics 21, 123-142.

Goldstein, Michael A., Edith S. Hotchkiss, and Erik R. Sirri, 2007, Transparency and Liquidity: A Controlled Experiment on Corporate Bonds, Review of Financial Studies 20, 235-273.

Grinblatt, Mark, and Francis A. Longstaff, 2000, Financial Innovation and the Role of Derivative Securities: An Empirical Analysis of the U.S. Treasury's STRIPS Program, Journal of Finance 55, 1415-1436.

Gromb, Denis, and Dimitri Vayanos, 2002, Equilibrium and Welfare in Markets with Financial Constrained Arbitrageurs, Journal of Financial Economics 66, 361-407.

Grossman, Sanford J., and Merton H. Miller, 1988, Liquidity and Market Structure, Journal of Finance 43, 617-633.

Grossman, Sanford J., and Jean-Luc Vila, 1992, Optimal Dynamic Trading with 
Leverage Constraints, Journal of Financial and Quantitative Analysis 27, 151168.

Gurkaynak, Refet S., Brian Sack, and Johnathan H. Wright, 2006, The U.S. Treasury Yield Curve: 1961 to the Present, FEDS Working Paper 2006-28.

He, Zhiguo, and Arvind Krishnamurthy, 2013, Intermediary Asset Pricing, American Economic Review 103, 732-770.

He, Zhiguo, Bryan Kelly, and Asaf Manela, 2016, Intermediary Asset Pricing: New Evidence from Many Asset Classes, Working Paper, University of Chicago.

Huang, Jennifer, and Jiang Wang, 2009, Liquidity and Market Crashes, Review of Financial Studies 22, 2607-2643.

Huang, Jennifer, and Jiang Wang, 2010, Market Liquidity, Asset Prices, and Welfare, Journal of Financial Economics 95, 107-127.

Jordan, Bradford, Randy Jorgensen, and David Kuipers, 2000, The Relative Pricing of U.S. Treasury STRIPS, Journal of Financial Economics 46, 67-102.

Kahl, Matthias, Jun Liu, and Francis A. Longstaff, 2003, Paper Millionaires: How Valuable is Stock to a Stockholder Who is Restricted from Selling it?, Journal of Financial Economics 67, 385-410.

Kamara, Avi, 1994, Liquidity, Taxes, and Short-Term Treasury Yields, Journal of Financial and Quantitative Analysis 29, 403-417.

Kondor, Peter, and Dimitri Vayanos, 2015, Liquidity Risk and the Dynamics of Arbitrage Capital, Working Paper London School of Economics.

Kyle, Albert S., and Wei Xiong, 2001, Contagion as a Wealth Effect, Journal of Finance 56, 1401-1440.

Lamont, Owen A, and Richard H. Thaler, 2003, Can the Market Add and Subtract? Mispricing in Tech Stock Carve-outs, Journal of Political Economy 111, $227-268$.

Liu, Jun, and Francis A. Longstaff, 2004, Losing Money on Arbitrages: Optimal Dynamic Portfolio Choice in Markets with Arbitrage Opportunities, Review of Financial Studies 17, 611-641.

Longstaff, Francis A., 1995, How Much Can Marketability Affect Security Values?, Journal of Finance 50, 1767-1774.

Longstaff, Francis A., 2001, Optimal Portfolio Choice and the Valuation of Illiquid Securities, Review of Financial Studies 14, 407-431. 
Longstaff, Francis A., 2004, The Flight to Liquidity Premium in U.S. Treasury Bond Prices, Journal of Business 77, 511-526.

Longstaff, Francis. A., 2009, Portfolio Claustrophobia: Asset Pricing in Markets with Illiquid Assets, American Economic Review 99, 1119-1144.

Longstaff, Francis A., 2016, Valuing Thinly-Traded Assets, Management Science, forthcoming.

Longstaff, Francis A., Sanjay Mithal, and Eric Neis, 2005, Corporate Yield Spreads: Default Risk or Liquidity? New Evidence from the Credit Default Swap Market, Journal of Finance 60, 2213-2253.

Lynch, Anthony W., 1996, Decision Frequency and Synchronization Across Agents: Implications for Aggregate Consumption and Asset Returns, Journal of Finance 51, 1479-1497.

MacKinlay, A. Craig, and Krishna Ramaswamy, 1988, Index-Futures Arbitrage and the Behavior of Stock Index Futures Prices, Review of Financial Studies 1, $137-158$.

Mitchell, Mark, Todd Pulvino, Erik Stafford, 2002, Limited Arbitrage in Equity Markets, Journal of Finance 62, 551-584.

Nelson, Charles R., and Andrew F. Siegel, 1987, Parsimonious Modeling of Yield Curves, Journal of Business 60, 473-489.

Newey, Whitney K., and Kenneth D. West, 1987, A Simple, Positive Semidefinite, Heteroskedasticity and Autocorrelation Consistent Correlation Matrix, Econometrica 59, 703-708.

Nyborg, Kjell, and Per Östberg, 2014, Money and Liquidity in Financial Markets, Journal of Financial Economics 112, 30-52.

Ofek, Eli, Matthew Richardson, and Richard Whitelaw, 2004, Limited Arbitrage and Short Sale Restrictions: Evidence from the Options Market, Journal of Financial Economics 74, 305-342.

Pastor, Lubos, and Robert Stambaugh, 2003, Liquidity Risk and Expected Stock Returns, Journal of Political Economy 111, 642-685.

Roll, Richard, Eduardo Schwartz, and Avanidhar Subrahmanyam, 2007, Liquidity and the Law of One Price: The Case of the Futures-Cash Basis, Journal of Finance 62, 2201-2234.

Schwartz, Krista, 2016, Mind the Gap, Working paper, University of Pennsylvania. 
Shleifer, Andrei, and Robert W. Vishny, 1992, Liquidation Values and Debt Capacity: A Market Equilibrium Approach, Journal of Finance 47, 1343-1366.

Shleifer, Andrei, and Robert W. Vishny, 2011, Fire Sales in Finance and Macroeconomics, Journal of Economic Perspectives 25, 29-48.

Silber, William L., 1991, Discounts on Restricted Stock: The Impact of Illiquidity on Stock Prices, Financial Analysts Journal 47, 60-64.

Sundaresan, Suresh, Zhenyu Wang, and Wei Yang, 2016, Dynamics of the Expectation and Risk Premium in the OIS Term Structure, Working paper, Columbia University.

Thompson, Samuel B., 2011, Simple Formulas for Standard Errors that Cluster by Both Firm and Time, Journal of Financial Economics 99, 1-10.

Vayanos, Dimitri, 1998, Transaction Costs and Asset Prices: A Dynamic Equilibrium Model, Review of Financial Studies 11, 1-58.

Vayanos, Dimitri, and Jean-Luc Vila, 1999, Equilibrium Interest Rate and Liquidity Premium with Transaction Costs, Economic Theory 13, 509-539.

Vayanos, Dimitri, and Tan Wang, 2007, Search and Endogenous Concentration of Liquidity in Asset Markets, Journal of Economic Theory 136, 66-104.

Vayanos, Dimitri, and Pierre-Olivier Weill, 2008, A Search-Based Theory of the On-the-Run Phenomenon, Journal of Finance 63, 1361-1398.

Weill, Pierre-Olivier, 2007, Leaning Against the Wind, Review of Economic Studies 74, 1329-1354.

Wolinsky, Asher, 1990, Information Revelation in a Market with Pairwise Meetings, Econometrica 58, 1-23.

Xiong, Wei, 2001, Convergence Trading with Wealth Effects: An Amplification Mechanism in Financial Markets, Journal of Financial Economics 62, 247-292. 


\section{APPENDIX}

\section{A1. Estimating Dealer Inventory Holdings}

We use TRACE to estimate dealer inventory. Our version of TRACE contains dealer identifiers, allowing us to estimate inventory holdings for each dealer and bond issue. We estimate the inventory of the $j$ th dealer in the $i$ th bond on day $t$ as the cumulative difference between its buys and sells,

$$
I N V_{i, j, t}=\max \left(0, I N V_{i, j, t-1}+B U Y s_{i, j, t}-S E L L s_{i, j, t}\right) .
$$

Dealer inventory is constrained to be nonnegative. Most negative inventory observations occur in the period following a bonds issuance and are an artifact of primary market transactions not being recorded in TRACE. We use the dealer inventory estimates to identify the prime dealer for each bond. Specifically, the dealer with the largest average inventory position in a bond during the previous month is considered as the primary dealer for the bond.

As a robustness test, we also repeat the analysis when inventories are allowed to be negative to accommodate the possibility of short sales. The results are not significantly different because negative inventories tend to be small and occur predominantly during the period immediately following bond issuance. As a further robustness test and as an alternative to using dealer inventory, we identify the primary dealer as the dealer who handles most of the trading volume in a bond over the previous month. The two alternative procedures identify the same dealer as the prime dealer $65 \%$ of the time, and the main results are not sensitive to the procedure.

\section{A2. Liquidity Measures}

A number of metrics have been proposed to measure bond liquidity and trading activity. We compute the daily effective bid-ask spread of the $i$ th bond as the volume-weighted price difference between trades in which the $j$ th dealer sells and buys the same bond on a given day $t$, acting as a principal:

$$
B A_{i, t}=\sum_{j} w_{j, t}\left(P_{i, j, t}^{s a l e}-P_{i, j, t}^{b u y}\right)
$$

where $w_{j, t}$ is the $j$ th dealers share of the trading volume for the $i$ th bond on day $t$, and $P_{i, j}$ is the clean, volume-weighted price for which the $j$ th dealer sells or buys the $i$ th bond on day $t$. We include the prices of all principal transactions in which the dealer transacts with a non-dealer client. In a principal transaction 
the dealer trades with the client against his own inventory. By buying low and selling high, the dealer effectively earns a bid-ask spread, which compensates him for inventory costs, asymmetric information, and any other costs such as clearing and settlement (e.g., Glosten and Harris, 1988). In contrast, agency transactions are trades in which the dealer passes a bond on to the customers account from another dealer without taking on inventory risk. Agency transactions are not included because the dealers compensation consists of a fixed commission rather than a bid-ask spread. We also exclude interdealer trades because they typically involve much smaller price concessions than dealer-customer trades. To capture the price impact of trades, we compute the Amihud (2002) illiquidity measure, defined as the average price change per one million dollars traded, and estimated for each transaction and averaged by trading day:

$$
\text { Amihud }_{i, t}=\sum_{k} \frac{1,000,000}{N} \times \frac{P_{i, k}-P_{i, k-1}}{\text { Volume }_{i, k}}
$$

where $P_{i, k}$ is the price associated with $k$ th transaction in the $i$ th bond on day $t$, and $N$ is the total number of transactions on that day. Similar to the effective bid-ask spread, the Amihud measure is based on dealer-customer trades. We compute two measures of a bonds trading activity in each month: the number of trades and turnover. We count the number of institutional-sized trades (trades of $\$ 100,000$ or larger), and compute the trading volume and turnover, defined as the annualized ratio of the total trading volume relative to the outstanding amount.

\section{A3. State Income Tax Effects}

Appendix C of Elton, Gruber, Agrawal, and Mann (2001) shows that the effect of state income taxes on the yield of a one period coupon bond is proportional to $c \tau_{s}(1-\tau)$ (using our notation). To extend their analysis to longer maturity bonds, consider a $N$ year Treasury bond with coupon rate $c$ that trades at par. Recall that the yield to maturity on a coupon bond trading at par is the coupon rate of the bond. Now consider a $N$ year guaranteed corporate bond with the same coupon rate $c$, but which is subject to state income taxes. From an investor's after-tax perspective, the corporate bond is equivalent to a Treasury bond which pays a coupon of only $c\left(1-\tau_{s}(1-\tau)\right)$. Thus, for small values of the marginal state income tax rate, the difference in yields between the bonds can be closely approximated by $c \tau_{s}(1-\tau)$.

Given this representation of the state income tax effect, we can now estimate the value of $\tau_{s}(1-\tau)$ directly from a simple cross-sectional regression. Specifically, we regress yield spreads described in Section 6.1 on an intercept and the coupon rate for the bonds in a simple time series panel regression. The 
coefficient on the coupon rate provides a direct estimate of the marginal state income tax rate $\tau_{s}(1-\tau)$. The estimated regression coefficient is 0.01655 , which is statistically significant with a $t$-statistic of 2.76 based on the Newey and West (1987) estimator of the covariance matrix. 


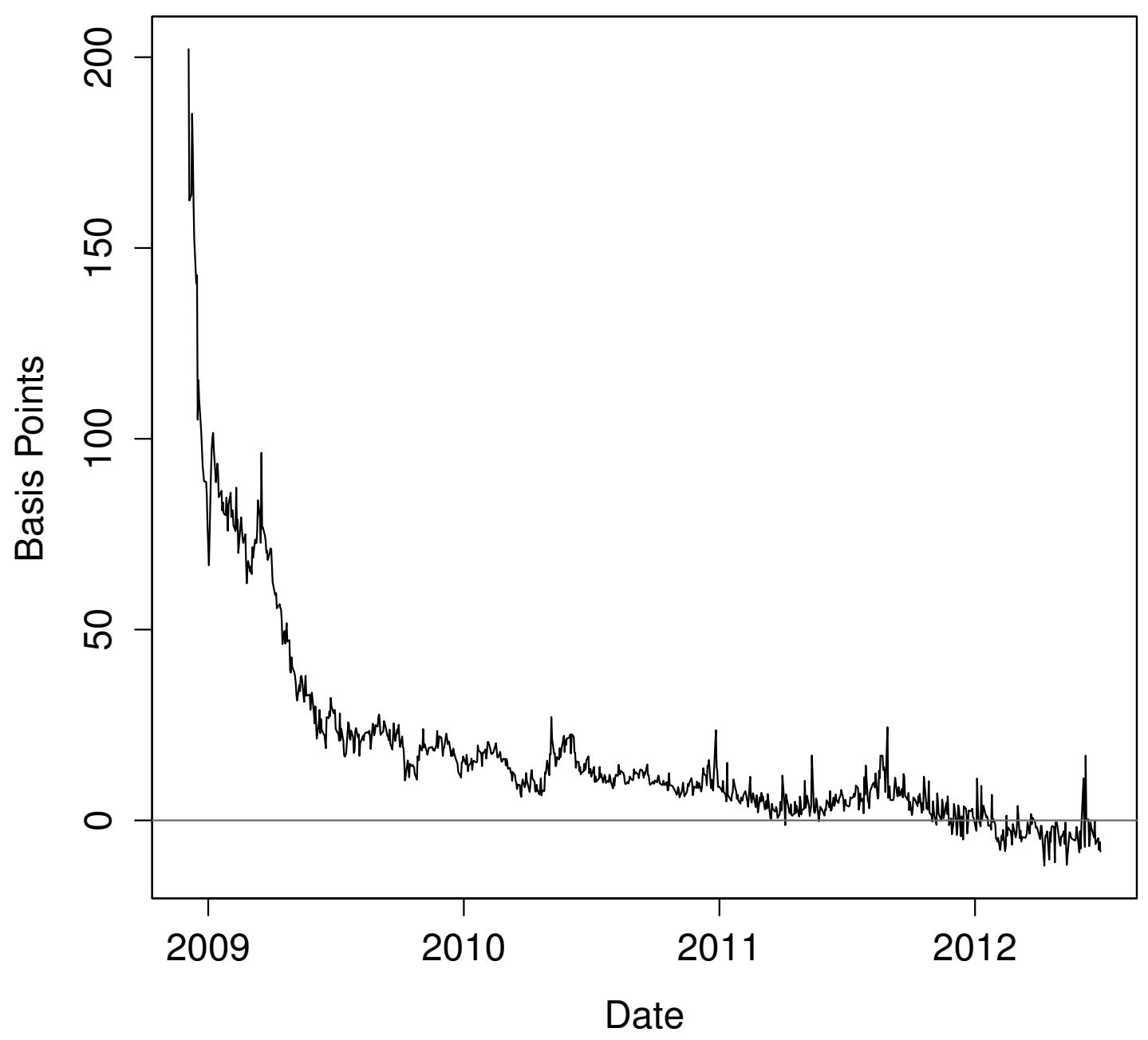

Figure 1. Average Mispricing. This figure plots the average mispricing of the guaranteed bonds over time. Average mispricing for a given date is computed by taking the average over all bonds in the sample on that date and is measured in basis points. 


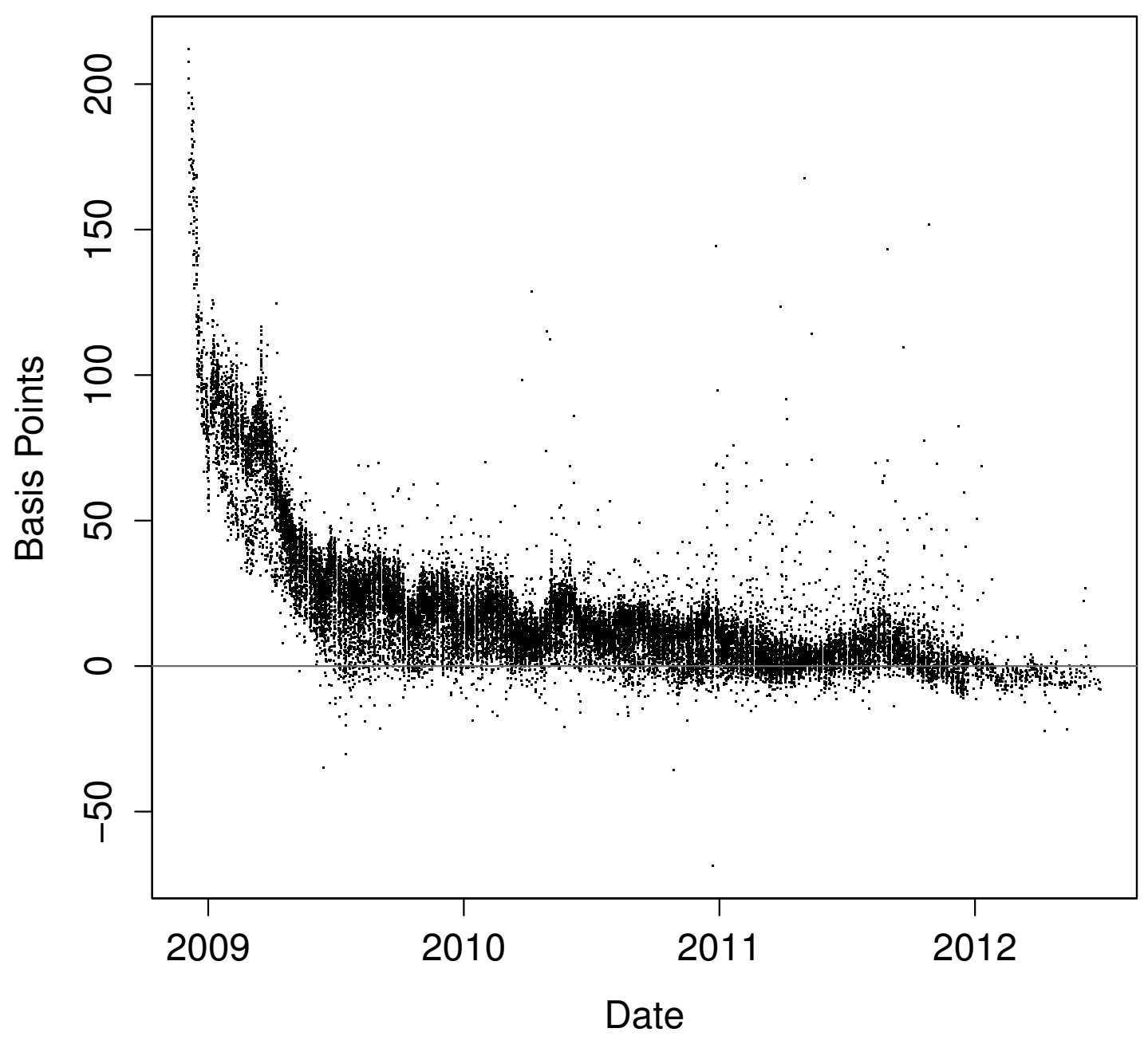

Figure 2. Mispricing of Individual Bonds. This figure plots the mispricing of the individual guaranteed bonds over time. Mispricing is measured in basis points. 


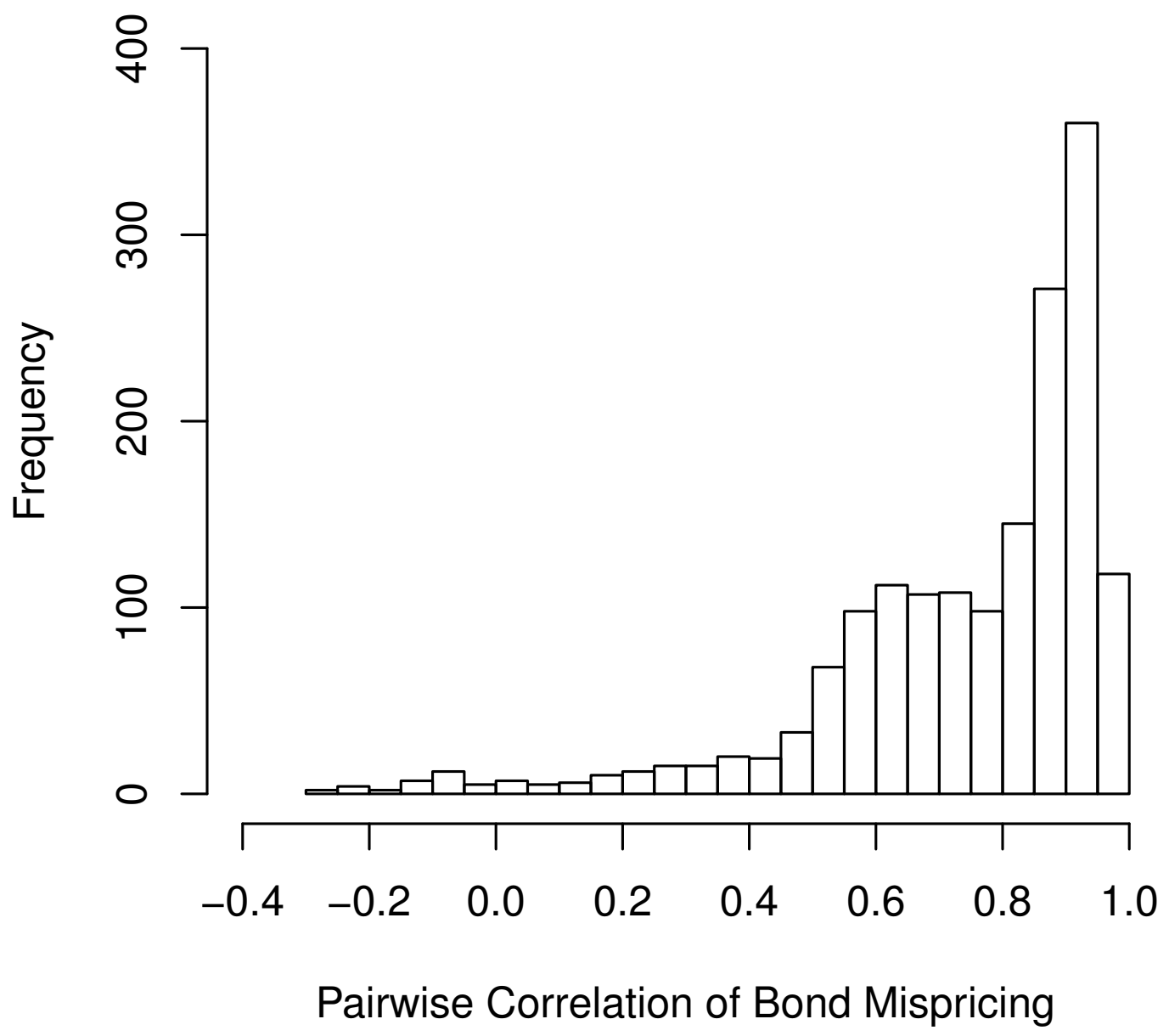

Figure 3. Distribution of Correlations. This figure plots the histogram of the pairwise correlations between the mispricing of the bonds in the sample. 
Effect of Mispricing on Haircuts
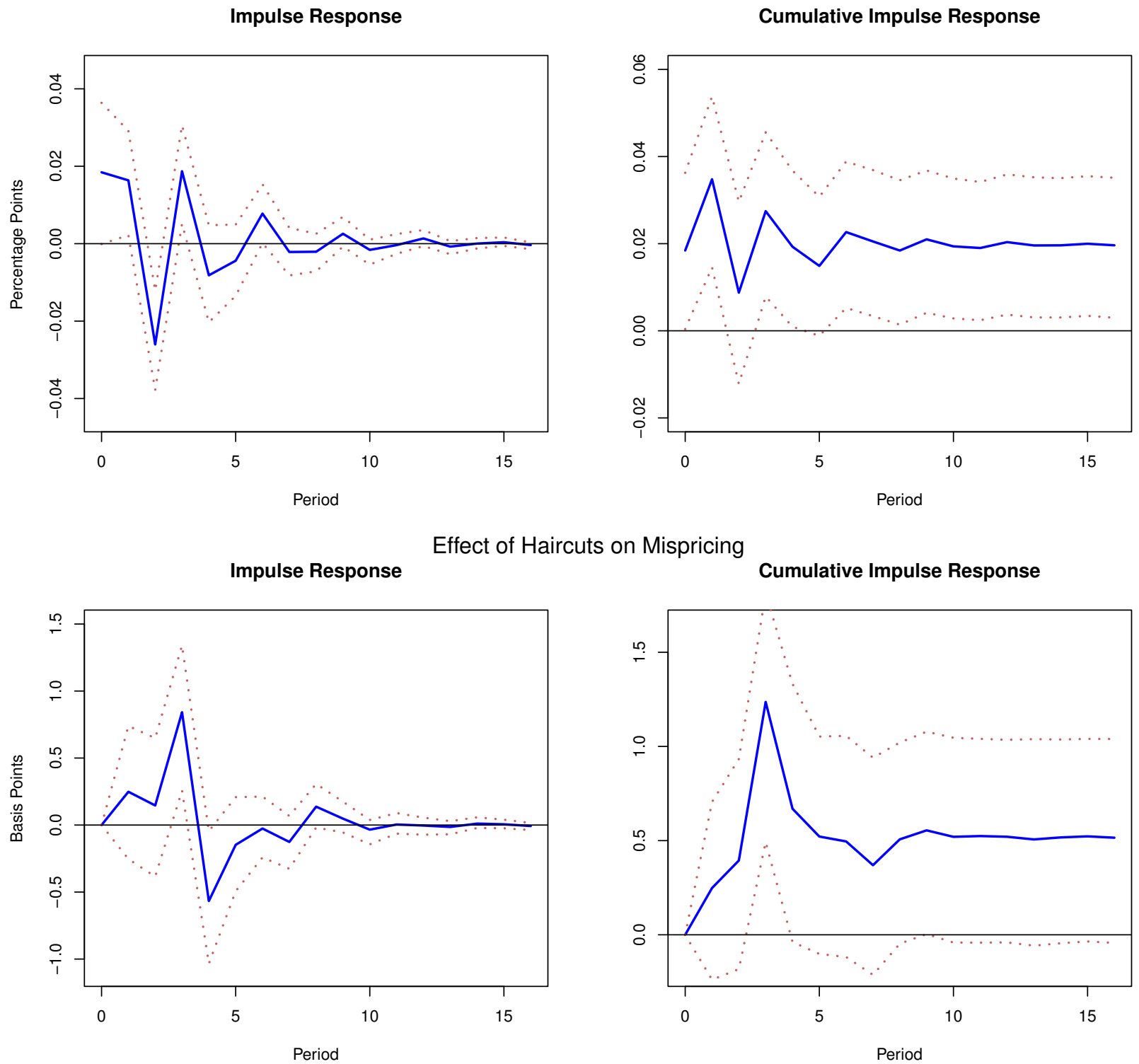

Figure 4. Impulse Response Functions for Mispricing and Haircuts. The upper two graphs plot the impulse and cumulative impulse response functions showing the effect of mispricing on haircuts. The lower two graphs plot the impulse and cumulative impulse response functions showing the effect of haircuts on mispricing. 
Effect of Mispricing on CDS
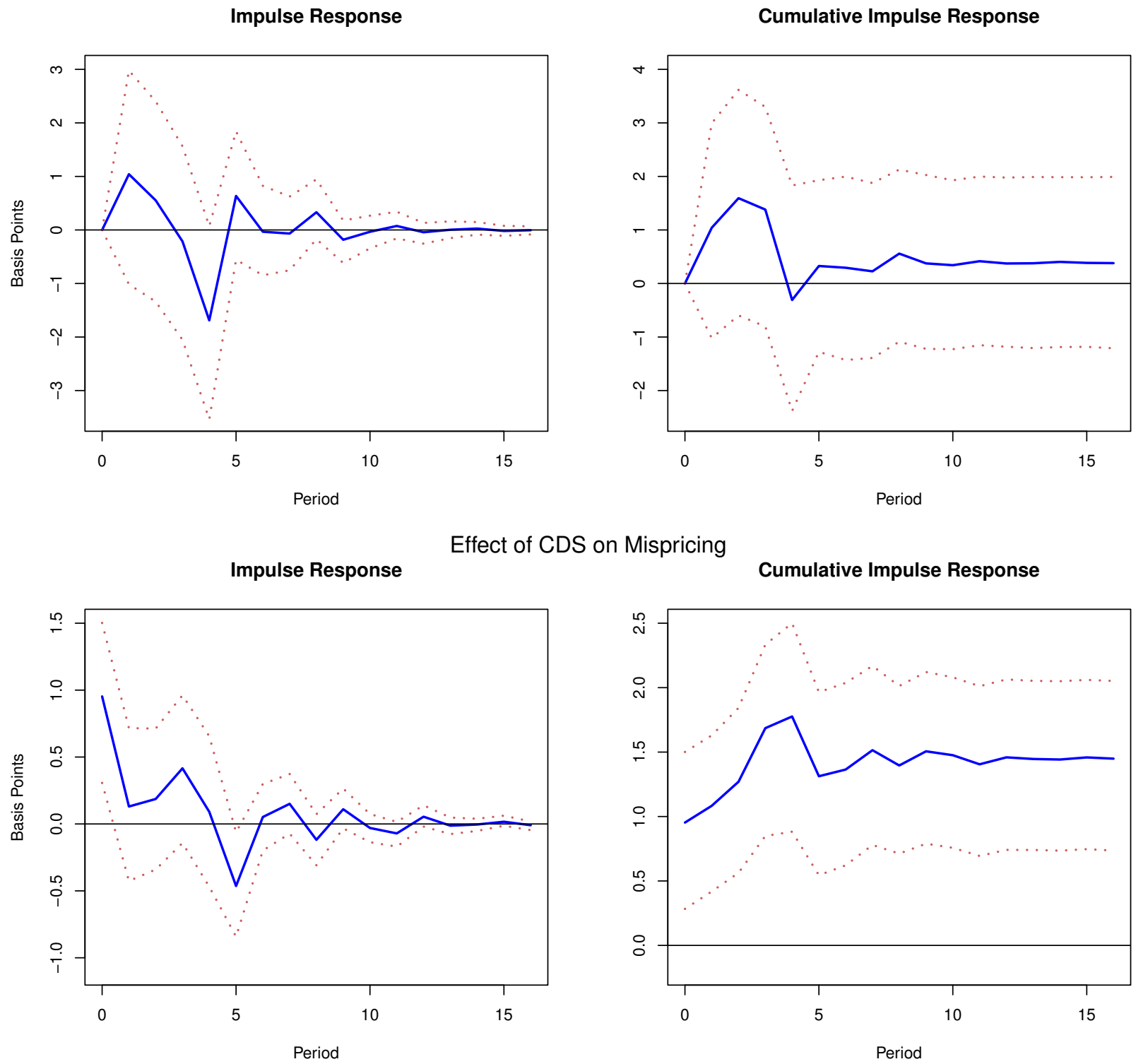

Cumulative Impulse Response

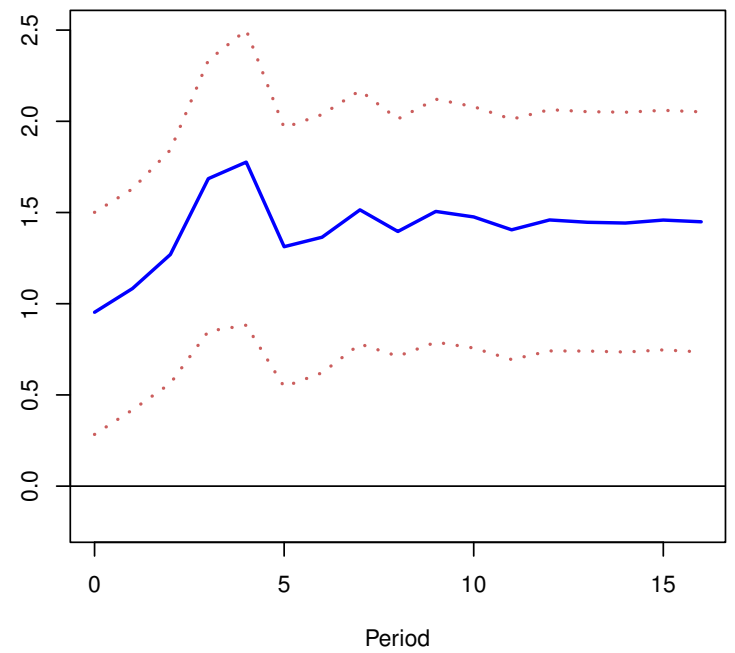

Figure 5. Impulse Response Functions for Mispricing and CDS Spreads. The upper two graphs plot the impulse and cumulative impulse response functions showing the effect of mispricing on dealer CDS spreads. The lower two graphs plot the impulse and cumulative impulse response functions showing the effect of dealer CDS spreads on mispricing. 

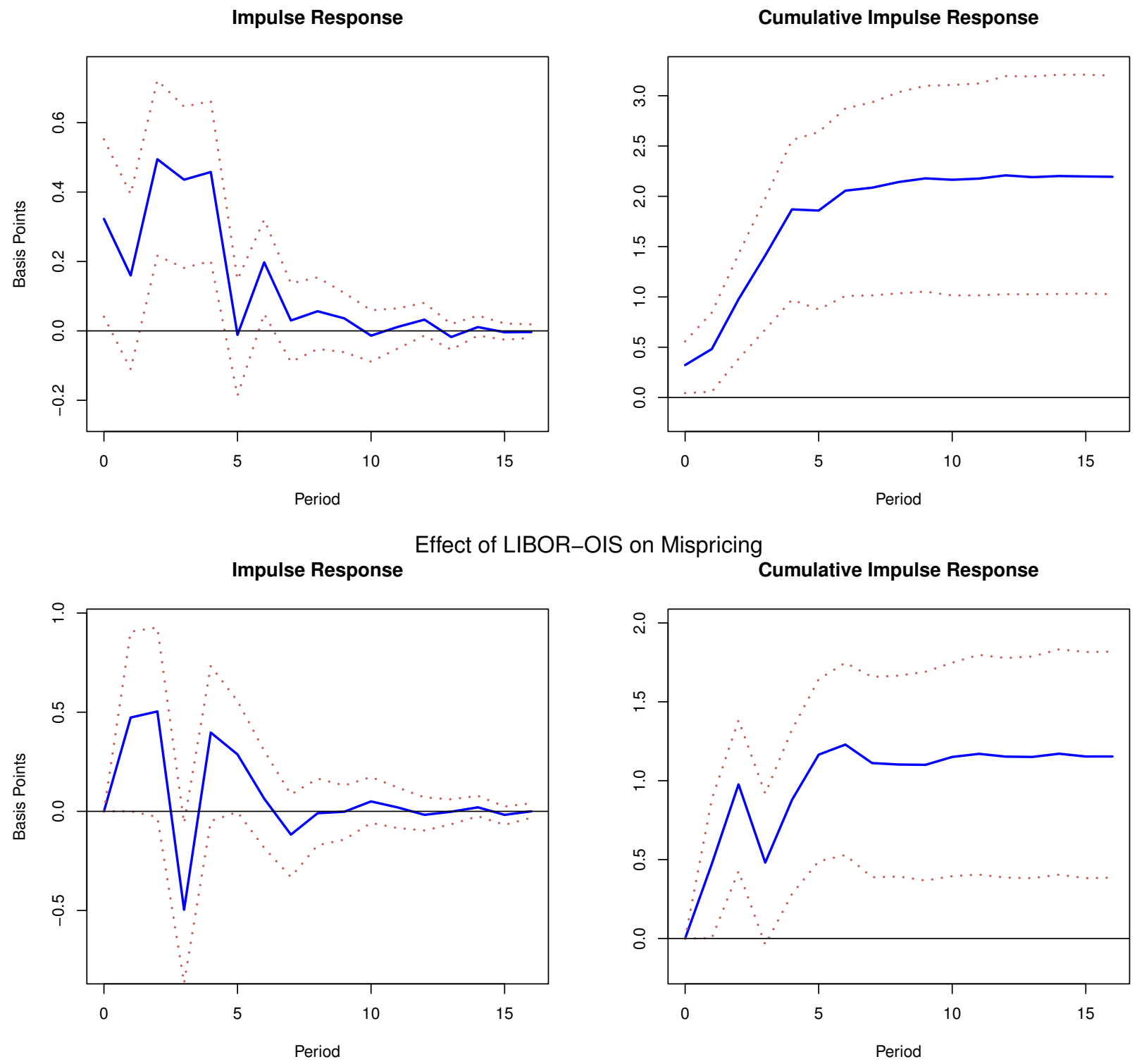

Figure 6. Impulse Response Functions for Mispricing and Libor-OIS Spreads. The upper two graphs plot the impulse and cumulative impulse response functions showing the effect of mispricing on the Libor-OIS spread. The lower two graphs plot the impulse and cumulative impulse response functions showing the effect of the Libor-OIS spread on mispricing. 
Table 1

Summary Statistics for Cross Sectional Explanatory Variables. This table presents summary statistics for the explanatory variables used in the cross sectional regressions for the mispricing of individual bond issues. for individual bond issues. The columns denoted $5 \%$, $50 \%$, and $95 \%$ represent the 5 th, 50 th, and 95 th percentiles of the distribution. $N$ denotes the number of observations. The sample period is

December 1, 2008 to December 26, 2012.

\begin{tabular}{|c|c|c|c|c|c|c|}
\hline Variable & Mean & St. Dev. & $5 \%$ & $50 \%$ & $95 \%$ & $N$ \\
\hline Coupon Rate (\%) & 2.32 & 0.55 & 1.38 & 2.15 & 3.25 & 1727 \\
\hline Bond Price & 102.01 & 1.07 & 100.43 & 101.94 & 103.93 & 1727 \\
\hline Issuer CDS Spread (bps) & 167.00 & 94.00 & 66.00 & 147.00 & 372.00 & 1727 \\
\hline Lead Underwriter CDS Spread (bps) & 180.00 & 84.00 & 84.00 & 159.00 & 372.00 & 1727 \\
\hline Prime Dealer CDS Spread (bps) & 174.00 & 78.00 & 79.00 & 154.00 & 355.00 & 1646 \\
\hline Lead Underwriter Haircut (\%) & 6.31 & 1.00 & 4.85 & 6.22 & 7.89 & 1727 \\
\hline Prime Dealer Haircut (\%) & 6.02 & 1.11 & 4.30 & 5.85 & 7.90 & 1646 \\
\hline Number of Dealers & 24.99 & 12.57 & 7.00 & 23.00 & 48.00 & 1727 \\
\hline Number of Investors & 54.80 & 29.92 & 10.00 & 53.00 & 109.00 & 1727 \\
\hline Dealer Inventory (\%) & 13.29 & 8.13 & 1.79 & 12.59 & 26.35 & 1727 \\
\hline Institutional Holdings (\%) & 15.45 & 8.40 & 4.44 & 13.52 & 32.76 & 1727 \\
\hline Amount Outstanding ( $\$ \mathrm{MM})$ & 2625.32 & 1779.26 & 500.00 & 2250.00 & 6000.00 & 1727 \\
\hline Bid-Ask Spread & 0.07 & 0.06 & 0.01 & 0.06 & 0.19 & 1727 \\
\hline Amihud Measure & 0.19 & 0.44 & 0.00 & 0.06 & 0.79 & 1727 \\
\hline
\end{tabular}


Table 2

Summary Statistics for Guaranteed Bond Yield Spreads. This table presents summary statistics for the yields spreads of the guaranteed bonds in the sample. Size is denoted in billions of dollars. $5 \%, 50 \%$, and $95 \%$ denote the 5 th, 50 th, and 95 th percentiles of the distribution. $N$ denotes the number of observations. The sample period is December 1, 2008 to December 26, 2012.

\begin{tabular}{|c|c|c|c|c|c|c|c|c|}
\hline \multicolumn{3}{|c|}{ Coupon } & \multirow{2}{*}{$\begin{array}{c}\text { Mean } \\
12.83\end{array}$} & \multirow{2}{*}{$\begin{array}{r}\text { St. Dev } \\
16.93\end{array}$} & \multirow{2}{*}{$\begin{array}{r}5 \% \\
-2.32\end{array}$} & \multirow{2}{*}{$\begin{array}{r}50 \% \\
10.32\end{array}$} & \multirow{2}{*}{$\begin{array}{r}95 \% \\
27.99\end{array}$} & \multirow{2}{*}{$\begin{array}{r}N \\
411\end{array}$} \\
\hline American Express & 3.150 & $12-2011$ & & & & & & \\
\hline Bank of America Corp. & 2.100 & $04-2012$ & 21.33 & 22.18 & -0.64 & 15.74 & 79.12 & 643 \\
\hline Bank of America Corp. & 3.125 & 06-2012 & 24.56 & 28.19 & 0.61 & 15.66 & 86.26 & 736 \\
\hline Bank of America Corp. & 2.375 & 06-2012 & 16.84 & 16.99 & -2.83 & 13.37 & 49.20 & 487 \\
\hline Bank of the West & 2.150 & 03-2012 & 18.78 & 17.85 & -1.64 & 14.97 & 56.05 & 263 \\
\hline Citibank & 1.625 & $03-2011$ & 9.75 & 10.33 & -4.92 & 8.35 & 24.85 & 167 \\
\hline Citibank & 1.500 & $07-2011$ & 12.74 & 10.26 & -3.78 & 12.81 & 28.24 & 236 \\
\hline Citibank & 1.375 & $08-2011$ & 10.72 & 9.83 & -3.81 & 10.32 & 25.40 & 280 \\
\hline Citibank & 1.250 & 09-2011 & 8.42 & 8.96 & -4.13 & 6.95 & 22.59 & 227 \\
\hline Citibank & 1.250 & $11-2011$ & 10.52 & 8.04 & -0.58 & 9.74 & 24.17 & 212 \\
\hline Citibank & 1.875 & $05-2012$ & 17.82 & 12.55 & 0.37 & 15.93 & 40.23 & 399 \\
\hline Citibank & 1.875 & 06-2012 & 16.66 & 12.62 & -2.27 & 15.39 & 37.31 & 278 \\
\hline Citigroup & 1.250 & 06-2011 & 12.12 & 10.94 & -5.58 & 14.48 & 25.76 & 131 \\
\hline Citigroup & 2.875 & $12-2011$ & 26.76 & 30.61 & 0.01 & 17.17 & 88.69 & 572 \\
\hline Citigroup & 2.000 & 03-2012 & 20.06 & 17.80 & -2.10 & 15.54 & 51.80 & 340 \\
\hline Citigroup & 2.125 & $04-2012$ & 22.77 & 22.13 & -0.19 & 17.02 & 80.30 & 651 \\
\hline Citigroup & 2.125 & $07-2012$ & 14.81 & 11.18 & -2.43 & 13.40 & 35.43 & 425 \\
\hline Citigroup & 1.875 & $10-2012$ & 15.14 & 11.27 & -3.14 & 15.23 & 33.74 & 570 \\
\hline Citigroup & 1.875 & $11-2012$ & 12.86 & 10.20 & -3.71 & 13.09 & 30.04 & 430 \\
\hline Citigroup & 2.250 & $12-2012$ & 14.10 & 10.96 & -4.25 & 14.07 & 30.64 & 605 \\
\hline General Electric & 1.625 & $01-2011$ & 20.14 & 21.39 & -0.31 & 10.33 & 64.04 & 323 \\
\hline General Electric & 1.800 & 03-2011 & 16.11 & 17.88 & -3.52 & 11.20 & 56.24 & 341 \\
\hline General Electric & 3.000 & $12-2011$ & 26.73 & 30.42 & 0.83 & 17.32 & 89.93 & 615 \\
\hline General Electric & 2.250 & 03-2012 & 19.14 & 18.91 & -0.64 & 15.03 & 59.77 & 498 \\
\hline General Electric & 2.200 & 06-2012 & 23.32 & 22.99 & 0.26 & 17.41 & 82.34 & 678 \\
\hline General Electric & 2.000 & 09-2012 & 13.29 & 10.72 & -3.68 & 12.89 & 31.06 & 533 \\
\hline General Electric & 2.450 & $12-2012$ & 14.62 & 13.74 & 2.42 & 11.90 & 44.51 & 9 \\
\hline
\end{tabular}


Table 2 Continued

\begin{tabular}{|c|c|c|c|c|c|c|c|c|}
\hline Issuer & Coupon & Maturity & Mean & St. Dev & $5 \%$ & $50 \%$ & $95 \%$ & $N$ \\
\hline Goldman Sachs & 1.700 & 03-2011 & 13.94 & 16.50 & -1.33 & 8.20 & 51.00 & 256 \\
\hline Goldman Sachs & 1.625 & $07-2011$ & 19.07 & 20.74 & -3.97 & 14.47 & 70.74 & 469 \\
\hline Goldman Sachs & 2.150 & 03-2012 & 17.23 & 17.90 & -1.57 & 13.37 & 62.31 & 325 \\
\hline Goldman Sachs & 3.250 & 06-2012 & 24.21 & 27.44 & 0.26 & 15.84 & 82.47 & 740 \\
\hline $\mathrm{HSBC}$ & 3.125 & $12-2011$ & 23.47 & 28.10 & -1.24 & 13.53 & 87.71 & 526 \\
\hline John Deere & 2.875 & 06-2012 & 22.05 & 23.55 & -0.75 & 14.40 & 81.54 & 681 \\
\hline JP Morgan Chase & 2.625 & $12-2010$ & 21.02 & 29.04 & -2.37 & 8.10 & 87.04 & 342 \\
\hline JP Morgan Chase & 1.650 & $02-2011$ & 16.11 & 17.89 & -2.85 & 9.31 & 54.71 & 296 \\
\hline JP Morgan Chase & 3.125 & $12-2011$ & 25.11 & 30.69 & 0.71 & 14.34 & 84.31 & 614 \\
\hline JP Morgan Chase & 2.200 & 06-2012 & 19.36 & 18.20 & -0.29 & 15.36 & 66.84 & 559 \\
\hline JP Morgan Chase & 2.125 & 06-2012 & 23.12 & 23.59 & -1.09 & 16.41 & 78.70 & 607 \\
\hline JP Morgan Chase & 2.125 & $12-2012$ & 11.97 & 11.16 & -3.73 & 10.77 & 29.29 & 728 \\
\hline Keybank & 3.200 & 06-2012 & 22.83 & 25.63 & -2.26 & 15.32 & 80.90 & 600 \\
\hline Morgan Stanley & 2.900 & $12-2010$ & 22.61 & 30.87 & -1.71 & 10.20 & 83.60 & 351 \\
\hline Morgan Stanley & 2.000 & 09-2011 & 21.73 & 27.54 & -2.17 & 11.66 & 86.40 & 476 \\
\hline Morgan Stanley & 3.250 & $12-2011$ & 25.98 & 32.09 & -0.32 & 14.70 & 89.78 & 553 \\
\hline Morgan Stanley & 2.250 & 03-2012 & 19.38 & 19.04 & -0.85 & 14.88 & 61.82 & 424 \\
\hline Morgan Stanley & 1.950 & 06-2012 & 21.21 & 21.98 & -0.49 & 15.32 & 77.93 & 568 \\
\hline NY Community Bank & 3.000 & $12-2011$ & 37.30 & 37.38 & -0.52 & 22.35 & 109.19 & 291 \\
\hline NY Community Bank & 2.550 & 06-2012 & 19.48 & 28.34 & -3.05 & 12.94 & 108.46 & 29 \\
\hline Oriental Bank & 2.750 & 03-2012 & 40.33 & 38.16 & 3.86 & 25.60 & 110.30 & 29 \\
\hline $\mathrm{PNC}$ & 1.875 & 06-2011 & 26.47 & 29.58 & -5.35 & 18.06 & 86.35 & 243 \\
\hline $\mathrm{PNC}$ & 2.300 & 06-2012 & 22.22 & 23.83 & -1.55 & 14.79 & 81.21 & 647 \\
\hline Regions Bank & 2.750 & $12-2010$ & 23.92 & 30.96 & -2.23 & 10.09 & 93.78 & 278 \\
\hline Regions Bank & 3.250 & $12-2011$ & 26.43 & 32.09 & -1.22 & 15.86 & 98.56 & 552 \\
\hline Sovereign Bank & 2.750 & $01-2012$ & 27.69 & 30.55 & -0.23 & 16.29 & 94.61 & 418 \\
\hline Sovereign Bank & 2.500 & 06-2012 & 29.69 & 29.06 & -3.11 & 19.87 & 89.56 & 159 \\
\hline State Street & 1.850 & 03-2011 & 13.81 & 16.20 & -5.12 & 9.35 & 47.50 & 250 \\
\hline State Street & 2.150 & 04-2012 & 18.64 & 19.89 & -2.03 & 14.69 & 60.95 & 517 \\
\hline Suntrust & 3.000 & $11-2011$ & 24.99 & 29.21 & -1.15 & 16.24 & 88.04 & 517 \\
\hline US Bancorp & 2.250 & 03-2012 & 16.76 & 17.17 & -3.51 & 13.60 & 53.87 & 409 \\
\hline US Bancorp & 1.800 & 05-2012 & 15.05 & 11.76 & -2.78 & 13.78 & 35.74 & 314 \\
\hline Wells Fargo & 3.000 & $12-2011$ & 22.95 & 25.72 & -0.07 & 15.24 & 74.83 & 585 \\
\hline Wells Fargo & 2.125 & 06-2012 & 14.45 & 13.29 & -3.26 & 11.86 & 37.03 & 488 \\
\hline All & & & 20.07 & 23.13 & -1.77 & 14.07 & 76.35 & 26482 \\
\hline
\end{tabular}


Table 3

Commonality in Mispricing. This table presents the results from a principal components analysis of mispricing for the 58 bonds with more than 100 observations during the sample period. Percentage denotes the percentage of total variation explained by the indicated principal component. Cumulative denotes the cumulative percentage of total variation explained using the indicated number of principal components.

\begin{tabular}{l|rc}
\hline Principal Component & Percentage & Cumulative \\
\hline & & \\
\hline & & 66.13 \\
3 & 66.13 & 78.60 \\
4 & 12.47 & 82.12 \\
5 & 3.52 & 84.99 \\
6 & 2.87 & 87.12 \\
7 & 2.13 & 88.75 \\
& 1.63 & 90.10 \\
\hline
\end{tabular}


Table 4

Results from the Time Series Regression of Weekly Changes in Average Mispricing on Explanatory Variables. This tables reports summary statistics for the regressions of the weekly change in average mispricing on the indicated variables. The $t$-statistics are based on the Newey-West (1980) estimator of the covariance matrix (four lags). The superscripts ${ }^{*}$ and ${ }^{* *}$ denote significance at the ten-percent and five-percent levels, respectively. The sample period is weekly from December 2008 to December 2012.

\begin{tabular}{|c|c|c|c|c|c|c|c|c|c|}
\hline Variable & Lag & Coeff. & $t$-stat & Coeff. & $t$-stat & Coeff. & $t$-stat & Coeff. & $t$-stat \\
\hline Intercept & & -0.918 & $-2.75^{* *}$ & -0.997 & $-3.05^{* *}$ & -0.942 & $-3.07^{* *}$ & -0.909 & $-3.00^{* *}$ \\
\hline Change in Mispricing & 1 & -0.468 & $-3.64^{* *}$ & -0.525 & $-4.30^{* *}$ & -0.480 & $-5.30^{* *}$ & -0.468 & $-5.26^{* *}$ \\
\hline Change in Mispricing & 2 & -0.260 & $-2.95^{* *}$ & -0.310 & $-3.97^{* *}$ & -0.283 & $-3.40^{* *}$ & -0.284 & $-3.41^{* *}$ \\
\hline Change in Mispricing & 3 & -0.102 & -1.34 & -0.133 & $-2.10^{* *}$ & -0.120 & -1.53 & -0.129 & -1.59 \\
\hline Change in Mispricing & 4 & -0.051 & -1.09 & -0.052 & -1.02 & -0.122 & $-2.08^{* *}$ & -0.124 & $-1.89^{*}$ \\
\hline Change in Haircut & 0 & 4.308 & $2.57^{* *}$ & 4.455 & $2.63^{* *}$ & 6.130 & $2.52^{* *}$ & 5.982 & $2.46^{* *}$ \\
\hline Change in Haircut & 1 & 2.158 & 1.07 & 1.844 & 0.98 & 4.699 & 1.54 & 4.416 & 1.51 \\
\hline Change in Haircut & 2 & 2.832 & 1.38 & 2.298 & 1.25 & 4.277 & $1.70^{*}$ & 4.046 & $1.66^{*}$ \\
\hline Change in Haircut & 3 & 8.804 & $4.48^{* *}$ & 8.661 & $4.43^{* *}$ & 9.731 & $4.10^{* *}$ & 10.249 & $4.03^{* *}$ \\
\hline Change in Haircut & 4 & 1.208 & 0.74 & 2.401 & 1.49 & 3.941 & $2.19^{* *}$ & 4.069 & $2.00^{* *}$ \\
\hline Change in CDS Spread & 0 & & & 0.048 & $2.43^{* *}$ & 0.041 & $2.15^{* *}$ & 0.037 & $1.85^{*}$ \\
\hline Change in CDS Spread & 1 & & & 0.037 & $2.09^{* *}$ & 0.025 & 1.62 & 0.023 & 1.40 \\
\hline Change in CDS Spread & 2 & & & 0.033 & $2.33^{* *}$ & 0.015 & 1.08 & 0.014 & 0.96 \\
\hline Change in CDS Spread & 3 & & & 0.039 & $2.65^{* *}$ & 0.027 & $1.69^{*}$ & 0.028 & $1.71^{*}$ \\
\hline Change in CDS Spread & 4 & & & 0.026 & 1.39 & 0.025 & 1.47 & 0.023 & 1.35 \\
\hline Change in Libor-OIS & 0 & & & & & 0.309 & $2.31^{* *}$ & 0.311 & $2.01^{* *}$ \\
\hline Change in Libor-OIS & 1 & & & & & 0.157 & 1.13 & 0.145 & 1.13 \\
\hline Change in Libor-OIS & 2 & & & & & 0.113 & 0.81 & 0.115 & 0.69 \\
\hline Change in Libor-OIS & 3 & & & & & -0.373 & $-2.10^{* *}$ & -0.351 & $-1.94^{*}$ \\
\hline Change in Libor-OIS & 4 & & & & & 0.021 & 0.19 & 0.001 & 0.01 \\
\hline Change in Volatility & 0 & & & & & & & -0.007 & -0.18 \\
\hline Change in Volatility & 1 & & & & & & & 0.024 & 0.69 \\
\hline Change in Volatility & 2 & & & & & & & -0.001 & -0.03 \\
\hline Change in Volatility & 3 & & & & & & & -0.003 & -0.08 \\
\hline Change in Volatility & 4 & & & & & & & 0.044 & 1.12 \\
\hline Adjusted $R^{2}$ & & & 0.267 & & 0.328 & & 0.371 & & 0.368 \\
\hline Number of Observations & & & 182 & & 182 & & 182 & & 182 \\
\hline
\end{tabular}




\section{Table 5}

Results from the Vector Autoregressions. This table reports summary statistics from vector autoregressions for weekly changes in average mispricing, haircuts, and dealer CDS spreads. Average mispricing is expressed in dollars per $\$ 100$ notional amount. Average haircut is expressed as a percentage of the notional amount of the bond. Average CDS spread is expressed in basis points. The superscripts * and $* *$ denote significance at the ten-percent and five-percent levels, respectively. The sample period is weekly from December 2008 to December 2012

\begin{tabular}{|c|c|c|c|c|c|c|c|}
\hline \multirow[b]{2}{*}{ Variable } & \multirow[b]{2}{*}{ Lag } & \multicolumn{2}{|c|}{ Change in Mispricing } & \multicolumn{2}{|c|}{ Change in Haircut } & \multicolumn{2}{|c|}{ Change in CDS Spread } \\
\hline & & Coeff. & $t$-stat & Coeff. & $t$-stat & Coeff. & $t$-stat \\
\hline Intercept & & -0.991 & $-3.09^{* *}$ & 0.001 & 0.11 & 0.026 & 0.02 \\
\hline Change in Mispricing & 1 & -0.495 & $-7.23^{* *}$ & 0.005 & $2.27^{* *}$ & 0.175 & 0.55 \\
\hline Change in Mispricing & 2 & -0.314 & $-4.93^{* *}$ & -0.003 & $-1.70^{*}$ & 0.221 & 0.75 \\
\hline Change in Mispricing & 3 & -0.108 & $-2.03^{* *}$ & 0.002 & 1.44 & 0.291 & 1.19 \\
\hline Change in Mispricing & 4 & -0.065 & -1.23 & 0.000 & 0.08 & -0.270 & -1.12 \\
\hline Change in Haircut & 1 & 1.939 & 0.79 & -0.175 & $-2.30^{* *}$ & 18.052 & 1.60 \\
\hline Change in Haircut & 2 & 1.883 & 0.76 & -0.034 & -0.44 & -5.435 & -0.48 \\
\hline Change in Haircut & 3 & 7.825 & $3.23^{* *}$ & -0.005 & -0.06 & -16.861 & -1.51 \\
\hline Change in Haircut & 4 & 0.890 & 0.37 & -0.157 & $-2.09^{* *}$ & -16.785 & -1.51 \\
\hline Change in CDS Spread & 1 & 0.031 & $1.86^{*}$ & 0.001 & 1.10 & -0.185 & $-2.43^{* *}$ \\
\hline Change in CDS Spread & 2 & 0.032 & $1.90^{*}$ & -0.001 & -1.47 & 0.047 & 0.61 \\
\hline Change in CDS Spread & 3 & 0.035 & $2.05^{* *}$ & -0.001 & $-1.71^{*}$ & -0.015 & -0.20 \\
\hline Change in CDS Spread & 4 & 0.024 & 1.40 & 0.001 & $1.71^{*}$ & -0.137 & $-1.77^{*}$ \\
\hline Adjusted $R^{2}$ & & & 0.287 & & 0.133 & & 0.047 \\
\hline Number of Observations & & & 182 & & 182 & & 182 \\
\hline
\end{tabular}


Table 6

Results from the Cross Sectional Regression of Mispricing on Explanatory Variables. This tables reports summary statistics for the cross sectional regressions of bond-specific mispricing on the indicated variables. Time to maturity is in years. Coupon rate is expressed as a percentage. Issuer, lead underwriter, and prime dealer CDS spreads are measured in basis points. Inventory denotes the total inventory holdings of dealers as a percentage of the size of the bond issue. Institutional holdings are expressed as percentage of the size of the bond issue. Lead underwriter and prime dealer haircuts are expressed as a percentage of the value of the bond. Size of the issue and trading volume are measured in dollars. The bid-ask spread is measured as a fraction of the par amount of the bond. The Amihud measure is expressed are measured in dollars. The bid-ask spread is measured as a fraction of the par amount of the bond. The Amihud measure is expressed as a fraction of the par amount. Medium-term note takes value one if the bond issue is a medium-term note, and zero otherwise. Standard respectively. The sample period is monthly from December 2008 to December 2012.

\begin{tabular}{|c|c|c|c|c|c|c|c|c|c|c|}
\hline Variable & Coeff. & $t$-stat & Coeff. & $t$-stat & Coeff. & $t$-stat & Coeff. & $t$-stat & Coeff. & $t$-stat \\
\hline Time to Maturity & 10.286 & $9.33^{* *}$ & 10.260 & $9.44^{* *}$ & 9.639 & $8.10^{* *}$ & 9.349 & $7.49^{* *}$ & 9.042 & $7.48^{* *}$ \\
\hline Coupon Rate & -0.001 & 0.00 & 0.129 & 0.23 & 0.274 & 0.59 & 0.465 & 0.84 & 0.070 & 0.17 \\
\hline Issuer CDS Spread & & & 0.009 & 1.42 & -0.002 & -0.28 & -0.000 & -0.07 & 0.000 & 0.11 \\
\hline Underwriter CDS Spread & & & & & 0.021 & $3.48^{* *}$ & 0.014 & $2.27^{* *}$ & 0.013 & $2.10^{* *}$ \\
\hline Prime Dealer CDS Spread & & & & & 0.010 & $2.02^{* *}$ & 0.011 & $2.36^{* *}$ & 0.012 & $2.40^{* *}$ \\
\hline Underwriter Haircut & & & & & 0.039 & 0.11 & 0.051 & 0.11 & -0.007 & -0.02 \\
\hline Prime Dealer Haircut & & & & & 0.543 & $2.08^{* *}$ & 0.500 & $2.20^{* *}$ & 0.549 & $2.33^{* *}$ \\
\hline Number of Dealers & & & & & & & -0.070 & $-1.67^{*}$ & -0.071 & $-1.72^{*}$ \\
\hline Number of Investors & & & & & & & 0.011 & 0.56 & 0.036 & 1.63 \\
\hline Inventory & & & & & & & -0.122 & $-5.90^{* *}$ & -0.141 & $-6.46^{* *}$ \\
\hline Institutional Holdings & & & & & & & -0.003 & -0.08 & -0.029 & -0.63 \\
\hline Log Size of Issue & & & & & & & & & -1.724 & $-2.99^{* *}$ \\
\hline Log Trading Volume & & & & & & & & & 0.781 & $2.82^{* *}$ \\
\hline Bid-Ask Spread & & & & & & & & & 0.045 & 0.83 \\
\hline Amihud Measure & & & & & & & & & -0.478 & -1.41 \\
\hline Medium-Term Note & & & & & & & & & 0.010 & 0.02 \\
\hline Time Fixed Effects & & Yes & & Yes & & Yes & & Yes & & Yes \\
\hline Issuer Fixed Effects & & No & & No & & No & & No & & No \\
\hline Adjusted $R^{2}$ & & 0.552 & & 0.601 & & 0.630 & & 0.654 & & 0.685 \\
\hline Number of Observations & & 1646 & & 1646 & & 1646 & & 1646 & & 1646 \\
\hline
\end{tabular}


Table 7

Results from the Cross Sectional Regression of Mispricing on Explanatory Variables with Issuer Fixed Effects. This table reports summary statistics for the cross sectional regressions of bond-specific mispricing on the indicated variables. Time to maturity is in years. Coupon rate is expressed as a percentage. Issuer, lead underwriter, and prime dealer CDS spreads are measured in basis points. Inventory denotes the total inventory holdings of dealers as a percentage of the size of the bond issue. Institutional holdings are expressed as percentage of the size of the bond issue. Lead underwriter and prime dealer haircuts are expressed as a percentage of the value of the bond. Size of the issue and trading volume are measured in dollars. The bid-ask spread is measured as a fraction of the par amount of the bond. The Amihud issue and trading volume are measured in dollars. The bid-ask spread is measured as a fraction of the par amount of the bond. The Amihud otherwise. Standard errors are clustered at the issuer and monthly level. The superscripts * and ** denote significance at the ten-percent and five-percent levels, respectively. The sample period is monthly from December 2008 to December 2012.

\begin{tabular}{|c|c|c|c|c|c|c|c|c|c|c|}
\hline Variable & Coeff. & $t$-stat & Coeff. & $t$-stat & Coeff. & $t$-stat & Coeff. & $t$-stat & Coeff. & $t$-stat \\
\hline $\begin{array}{l}\text { Time to Maturity } \\
\text { Coupon Rate }\end{array}$ & $\begin{array}{r}10.091 \\
0.699\end{array}$ & $\begin{array}{l}9.33^{* *} \\
1.39\end{array}$ & $\begin{array}{r}10.104 \\
0.669\end{array}$ & $\begin{array}{l}9.28^{* *} \\
1.29\end{array}$ & $\begin{array}{l}9.584 \\
0.563\end{array}$ & $\begin{array}{l}7.92^{* *} \\
1.04\end{array}$ & $\begin{array}{l}9.180 \\
1.117\end{array}$ & $\begin{array}{l}8.14^{* *} \\
1.50\end{array}$ & $\begin{array}{l}8.907 \\
1.075\end{array}$ & $\begin{array}{l}7.76^{* *} \\
1.64\end{array}$ \\
\hline Issuer CDS Spread & & & 0.006 & 0.92 & -0.001 & -0.15 & -0.002 & -0.32 & -0.001 & -0.30 \\
\hline $\begin{array}{l}\text { Underwriter CDS Spread } \\
\text { Prime Dealer CDS Spread } \\
\text { Underwriter Haircut } \\
\text { Prime Dealer Haircut }\end{array}$ & & & & & $\begin{array}{r}0.018 \\
0.011 \\
-0.058 \\
0.495\end{array}$ & $\begin{aligned} & 2.58^{* *} \\
& 1.88^{*} \\
- & 0.11 \\
& 1.72^{*}\end{aligned}$ & $\begin{array}{r}0.016 \\
0.012 \\
-0.193 \\
0.454\end{array}$ & $\begin{aligned} & 2.27^{* *} \\
& 2.08^{* *} \\
&- 0.37 \\
& 1.79^{*}\end{aligned}$ & $\begin{array}{r}0.016 \\
0.011 \\
-0.240 \\
0.487\end{array}$ & $\begin{aligned} & 2.33^{* *} \\
& 1.96^{* *} \\
&-0.46 \\
& 1.89^{*}\end{aligned}$ \\
\hline $\begin{array}{l}\text { Number of Dealers } \\
\text { Number of Investors } \\
\text { Inventory } \\
\text { Institutional Holdings }\end{array}$ & & & & & & & $\begin{array}{r}-0.081 \\
0.017 \\
-0.109 \\
-0.021\end{array}$ & $\begin{aligned}- & 1.57 \\
& 0.79 \\
- & 4.99^{* *} \\
- & 0.38\end{aligned}$ & $\begin{array}{r}-0.100 \\
0.033 \\
-0.128 \\
-0.040\end{array}$ & $\begin{array}{l}-1.81^{*} \\
1.43 \\
-5.17^{* *} \\
-0.69\end{array}$ \\
\hline $\begin{array}{l}\text { Log Size of Issue } \\
\text { Log Trading Volume } \\
\text { Bid-Ask Spread } \\
\text { Amihud Measure } \\
\text { Medium-Term Note }\end{array}$ & & & & & & & & & $\begin{array}{r}-1.255 \\
0.670 \\
0.064 \\
-0.125 \\
0.882\end{array}$ & $\begin{aligned} &- 1.83^{*} \\
& 1.96^{* *} \\
& 1.47 \\
&-0.57 \\
& 1.64\end{aligned}$ \\
\hline $\begin{array}{l}\text { Time Fixed Effects } \\
\text { Issuer Fixed Effects }\end{array}$ & & $\begin{array}{l}\text { Yes } \\
\text { Yes }\end{array}$ & & $\begin{array}{l}\text { Yes } \\
\text { Yes }\end{array}$ & & $\begin{array}{l}\text { Yes } \\
\text { Yes }\end{array}$ & & $\begin{array}{l}\text { Yes } \\
\text { Yes }\end{array}$ & & $\begin{array}{l}\text { Yes } \\
\text { Yes }\end{array}$ \\
\hline $\begin{array}{l}\text { Adjusted } R^{2} \\
\text { Number of Observations }\end{array}$ & & $\begin{array}{r}0.564 \\
1646\end{array}$ & & $\begin{array}{r}0.628 \\
1646\end{array}$ & & $\begin{array}{r}0.654 \\
1646\end{array}$ & & $\begin{array}{r}0.669 \\
1646\end{array}$ & & $\begin{array}{r}0.690 \\
1646\end{array}$ \\
\hline
\end{tabular}

